medRxiv preprint doi: https://doi.org/10.1101/2021.03.17.21253408; this version posted March 24, 2021. The copyright holder for this preprint (which was not certified by peer review) is the author/funder, who has granted medRxiv a license to display the preprint in All rights reserved. No reuse allowed without permission.

\title{
The tumor burden of metastatic colorectal cancer patients at initial diagnosis, pre- versus post-Covid-19 lockdown
}

Thierry AR, PhD; Pastor B, PhD, Pisareva E, MD PhD; Ghiringhelli F, MD PhD; Bouche O, MD PhD; De La Fouchardière C, MD PhD; Vanbockstael J, MD PhD; Smith D, MD PhD; François E, MD PhD; Dos Santos M, MD PhD; Botsen D, MD PhD; Ellis S MD, Fonck M, MD PhD; Andre T, MD PhD; Guardiola E, MD PhD; Khemissa F, MD PhD; Linot B, MD PhD; Martin-Babau J, MD; Rinaldi Y, MD PhD; Assenat E, MD PhD; Clavel L, MD PhD; Dominguez S, MD PhD; Gavoille C, MD PhD; Sefrioui D, MD PhD; Pezzella V, MS; Mollevi C, PhD; Ychou M, MD PhD; and Mazard T, MD PhD.

IRCM, Institut de Recherche en Cancérologie de Montpellier, INSERM U1194, Université de Montpellier, Institut régional du Cancer de Montpellier, Montpellier, F-34298, France. A.R Thierry; B. Pastor; E. Pisareva; C. Mollevi; M. Ychou; T. Mazard; F. Ghiringhelli, Centre Georges François Leclerc, Dijon, France; O. Bouche, Hôpital Robert Debré, Reims, France; C. De La Fouchardière, Centre Léon Bérard, Lyon, France; J. Vanbockstael, Institut de Cancérologie de I'Ouest (ICO) - Site Paul Papin - Site René Gauducheau, Angers - Saint Herblain, France; D. Smith, Hôpital Haut-Lévêque - CHU de Bordeaux, Pessac, France; E. François, Centre Antoine Lacassagne, Nice, France; M. Dos Santos, Centre François Baclesse, Caen, France; D. Botsen, Medical Oncology Department, Godinot Institute, Reims, France; S. Ellis, Centre Catalan d'Oncologie, Perpignan, France; M. Fonck, Institut Bergonié, Bordeaux, France; T. Andre, Sorbonne Université and Hôpital Saint-Antoine, Paris, France; E. Guardiola, Centre de Cancérologie du grand Montpellier, Montpellier, France; F. Khemissa, Centre Hospitalier de Perpignan, Perpignan, France; B. Linot, Hôpital Privé du Confluent, Nantes, France; J. MartinBabau, Centre CARIO, Plerin, France; Y. Rinaldi, Hôpital Européen de Marseille, Marseille, France; E. Assenat, Department of Medical Oncology, St Eloi University Hospital, Montpellier, France; L. Clavel, Hôpital Privé Jean Mermoz, Lyon, France; S. Dominguez, Hôpital Saint Vincent de Paul, Lille, France; C. Gavoille, Institut de Cancérologie de Lorraine, Vadoeuvre-les-Nancy, France; D. Sefrioui, CHU de Rouen, Rouen, France; V. Pezzella, UNICANCER, Paris, France.

Corresponding author: Prof. Alain R. Thierry, alain.thierry@inserm.fr IRCM, Institut de Recherche en Cancérologie de Montpellier, INSERM U1194, Institut régional du Cancer de Montpellier, Montpellier, F-34298, France.

Tel : +33663821994

Key words: colorectal cancer, COVID-19, diagnosis, tumor burden, lockdown, circulating DNA 
medRxiv preprint doi: https://doi.org/10.1101/2021.03.17.21253408; this version posted March 24, 2021. The copyright holder for this preprint (which was not certified by peer review) is the author/funder, who has granted medRxiv a license to display the preprint in All rights reserved. No reuse allowed without permission.

\begin{abstract}
Background: The COVID-19 pandemic led to a significant reduction in the provision of screening, case identification and hospital referrals to cancer patients. To our knowledge, no study has yet correlated quantitatively the consequences of these limitations for cancer patient management. This study evaluates the implications of such reductions for patients newly diagnosed with metastatic colorectal cancer ( $\mathrm{mCRC}$ ) in both the pre- and post-lockdown periods.
\end{abstract}

Methods: We examined 80 newly identified mCRC patients from 18 different clinical centers. These cases come from the screening procedure of a clinical trial which is using circulating DNA (cirDNA) analysis to determine their RAS and BRAF status.

Results: The tumor burden as evaluated by the median total plasma cirDNA concentration showed a statistically higher level in patients diagnosed post-lockdown compared to those diagnosed pre-lockdown (119.2 versus $17.3 \mathrm{ng} / \mathrm{mL} ; \mathrm{p}<0.0001$ ). In order to link tumor burden to survival, we compared the survival of these $\mathrm{mCRC}$ patients with previous studies in which cirDNA was examined in the same way (median survival, 16.2 months; median follow up, 48.7 months, $\mathrm{N}=135$ ). Given the poor survival rate of $\mathrm{mCRC}$ patients with high cirDNA levels (14.7 vs 20.0 and 8.8 vs 19.3 months median survival when dichotomizing the cohort by the median cirDNA concentration 24.4 and $100 \mathrm{ng} / \mathrm{mL}$, respectively), our study points to the potential deleterious consequences of the COVID-19 pandemic.

Conclusions: Recognizing that our exploratory study offers a snapshot of an evolving situation, our observations nonetheless clearly highlight the need to determine actions which would minimize delays in diagnosis during the ongoing and future waves of COVID-19. 
medRxiv preprint doi: https://doi.org/10.1101/2021.03.17.21253408; this version posted March 24, 2021. The copyright holder for this preprint (which was not certified by peer review) is the author/funder, who has granted medRxiv a license to display the preprint in All rights reserved. No reuse allowed without permission.

\section{Introduction:}

The unprecedented burden placed on health systems worldwide by the coronavirus disease 2019 (COVID-19) crisis has had numerous and significant implications for cancer care ${ }^{1}, 2,2$. People have been more reluctant to come to health services for fear of infection, particularly patients already diagnosed with cancer, given that cancer is considered a comorbidity. Cuts to (or indeed the suspension of) screening programs and diagnostic services in many countries have caused delays in diagnosis ${ }^{1}, 3,4,5$. To reduce the risk of SARS-Cov-2 exposure for cancer patients during therapy procedures, access to treatment has been restricted ${ }^{3}$. Lastly, the reprioritization of human resources and equipment to COVID-19 pandemic management has also resulted in the provision of sub-optimal or delayed care ${ }^{6}, 1$.

These implications have been exacerbated by the COVID containment measures enacted by different countries, which have tended to evolve from local and national recommendations and restrictions to local and national lockdowns ${ }^{1}{ }^{2}$. Such measures were initially seen in the first months of 2020 in Asia and Oceania, followed by Europe and the Americas in March, depending mainly on the date of the first SARS-Cov-2 infection cases in those areas ${ }^{2}$. The number of COVID patients necessitating hospitalization and critical care has placed an unprecedented burden on health services, and consequently limited their resources. Individual fears of contracting the virus, coupled with restrictions imposed on movement by the authorities, have generated additional barriers - both physical and psychological - for patients who need to access essential care.

To explore the indirect health effects of the COVID-19 pandemic on newly diagnosed cancer patients, we set out an observational study. To our knowledge, no other clinical evaluation exists of the impact of COVID-19 lockdowns on the tumor burden of cancer patients at initial diagnosis. We used cirDNA analysis to assess the patients' tumor burden. CirDNA is newlyidentified source of biological information, which has attracted the attention of researchers and clinicians in numerous fields ${ }^{7}$. Its clinical potential in oncology is significant, and includes molecular profiling, detection of residual disease, control of treatment efficacy, detection of clonal resistance, surveillance of recurrence, and screening ${ }^{8}$. CirDNA first showed its promise in contributing to companion tests as a "liquid biopsy;" it then acquired European Medicines Agency (EMA) approval for use in the detection of sensitizing and/or resistant somatic alterations in oncodrivers, such as in lung cancer and melanoma, as a tool to guide clinicians in selecting targeted therapies ${ }^{9}, 8$. Numerous works report that tumors secrete DNA into the blood stream in quantities proportional to their masses ${ }^{10}, 11,12$ especially in the case of metastatic colorectal cancer $(\mathrm{mCRC})^{10}, 13,14,15$. Thus, cirDNA offers analytical and clinical advantages over conventional antigenic biomarkers such as CEA, and may be considered as a surrogate marker of disease progression, at least in $\mathrm{mCRC}^{16}, 13,17,14,18,19$ (Suppl. Fig. 1).

\section{Methods:}

In this study, we included patients from the screening procedure of the ongoing UCGI 28 PANIRINOX study (NCT02980510/EudraCT n²016-001490-33), who were recruited before and after the lockdown enacted in France in the spring of 2020. The PANIRINOX study is a first line randomized phase II study, assessing the activity of a combination chemotherapy with 
medRxiv preprint doi: https://doi.org/10.1101/2021.03.17.21253408; this version posted March 24, 2021. The copyright holder for this

preprint (which was not certified by peer review) is the author/funder, who has granted medRxiv a license to display the preprint in

All rights reserved. No reuse allowed without permission.

fluorouracil, leucovorin, oxaliplatin and panitumumab \pm irinotecan (FOLFOX + panitumumab vs FOLFIRINOX + panitumumab ) in unresectable mCRC patients, selected by RAS and B-RAF status obtained from cirDNA analysis. It is the first interventional study to use cirDNA as a companion test for selecting mCRC patients towards anti-EGFR targeted therapy (Suppl. Information). That trial involves 31 French hospitals and cancer centers. The primary endpoint is the complete response rate, defined as the complete disappearance of metastatic lesions and CEA level normalization after a maximum of 12 treatment cycles Other major selection criteria are: age (between 18 and 75 years); ECOG performance status 0 or 1; absence of previous treatment for metastatic disease; and absence of use of oxaliplatin in an adjuvant setting (Suppl. Information). After they give written informed consent, patients are screened through a blood-sampling procedure to determine their RAS and BRAF tumor status according to plasma analysis of circulating cell free DNA, using Intplex technology ${ }^{20,21}$. Tumors considered as RAS/BRAF wild type are subsequently included in the PANIRINOX study if they fulfill all other inclusion criteria (Suppl. Information).

That ancillary study, therefore, benefits from the accuracy with which cirDNA can evaluate tumor burden, and from the trial's rigorous inclusion procedure and reporting, all of which supports the accuracy of assessment needed to achieve our objective. We examined all screened pre- and post-lockdown patients irrespective of their RAS and BRAF mutational status, in order to preclude any potential bias linked to mutational status. Given the interventional impact of cirDNA analysis in the PANIRINOX study, it is completed within five days of reception of the blood samples. In addition to cirDNA parameters analysis, we also collected, at the same time, demographic and clinico-biological parameters known to have prognosis value in this setting ${ }^{22},{ }^{23}$.

\section{Results:}

In France, the first mandatory home lockdown of 2020 lasted 55 days, from 17 March to 11 May. The PANIRINOX study screening was consequently interrupted on 19 March and resumed on 11 May (a 53-day interruption). Our study compared the cirDNA values determined in all patients $(N=40)$ screened from the May 14, 2020 up to September 3, 2020 (a 110 day period) to those found in all patients $(\mathrm{N}=40)$ screened before the lockdown (from 11 November 2019 up to 9 March 2020). Pre-analytical conditions of the cirDNA analysis followed strict guidelines and methodologies which have been previously validated ${ }^{24}, 20,21,25$. As observed in Figure 1, the cirDNA concentration median is 17.3 and $119.2 \mathrm{ng} / \mathrm{mL}$, before and after the lockdown, respectively (Suppl. Table 1 ). This represents a nearly 7 -fold increase. There is a high statistical difference between the two cohorts $(P<0.0001)$ (Figure 1 and 2). The values obtained in the patients included before lockdown $(\mathrm{N}=40)$ are similar to those obtained in all patients previously included from the start of the PANIRINOX study ( $\mathrm{N}=188$; starting 30 months before lockdown), showing a median cirDNA concentration of $13.0 \mathrm{ng} / \mathrm{mL}$ plasma (Figure 2). In addition, the cirDNA concentration values determined in all the 110 days fractional cohorts before lockdown from the start of the PANIRINOX study showed no statistical difference with the pre-lockdown study cohort $(\mathrm{N}=40)$ whereas they are statistically different as compared to the post-lockdown study cohort ( $\mathrm{N}=40)$ (Figure 2). 
medRxiv preprint doi: https://doi.org/10.1101/2021.03.17.21253408; this version posted March 24, 2021. The copyright holder for this preprint (which was not certified by peer review) is the author/funder, who has granted medRxiv a license to display the preprint in All rights reserved. No reuse allowed without permission.

This increase seen in cirDNA values post-lockdown is striking, and points to levels of tumor burden at diagnosis which have been shown to affect patient survival ${ }^{26}, 27,28$. To estimate the potential impact on survival of diagnostic delays arising from to lockdown, we retrospectively analyzed data accumulated during our last two clinical studies ${ }^{20},{ }^{21}$ from which we identified "all comers" newly diagnosed mCRC patients, and in which a rigorously identical methodology was used to assess cirDNA ( $\mathrm{N}=135)$ before patients began first line chemotherapy. The median cirDNA concentration ( $24.4 \mathrm{ng} / \mathrm{mL}$, range [2.3-1406], Suppl. Table 2) of these patients is similar to that observed in the pre-lockdown cohort studied from the PANIRINOX trial. As observed in Figure 3A, mCRC patient median survival in those two clinical studies (performed after a median follow up of 48.7 months, $95 \% \mathrm{Cl}$ [43.3-55.4] ) is 16.2 months ( $\mathrm{N}=135 ; 95 \% \mathrm{Cl}$ [13.620.6]). The median survival rate is low when compared with that seen in the latest literature up-to-date literature. This may be attributed to the starting date of these two clinical studies (2009 and 2014), and to a less stringent patient selection compared to the PANIRINOX study; it nonetheless fits within the median survival range as previously observed in a meta-analysis ${ }^{29}$ (16-23 months). When dichotomizing this cohort by the cirDNA concentration median value (24.4 ng/mL, range [2.3-1406]), patients diagnosed with higher cirDNA plasma amounts showed a statistically lower median survival (14.7 (95\% Cl [8.8-18.0]) vs 20.0 (95\% Cl [14.132.0]) months, HR: $1.74,95 \% \mathrm{Cl}$ [1.2-2.6]; $\mathrm{P}=0.005$ ) (Figure 3B, Suppl. Table 2). When dichotomizing the cohort by $100 \mathrm{ng} / \mathrm{mL}$, patients diagnosed with higher cirDNA plasma amounts also showed a statistically lower median survival $(8.80,95 \% \mathrm{Cl}[2.8-14.0]$ vs $19.3,95 \%$ $\mathrm{Cl}$ [2.8-14.0]) months; HR: 2.00, 95\% Cl [1.2-3.3] P=0.009) (Figure 3C, Suppl. Table 2). The comparative study of the lockdown impact (Figure 1) revealed 23 out of 40 patients (58\%) showing a cirDNA amount over $100 \mathrm{ng} / \mathrm{mL}$ post-lockdown, and only 6 out of 40 patients (15\%) above this concentration in pre-lockdown period. This could mean that 17 ( 23 minus 6 ) or $43 \%$ (58\% minus $15 \%$ ) supplementary patients diagnosed post-lockdown would have a median survival which is $54 \%$ (from 19.3 to $8.8 \mathrm{ng} / \mathrm{mL}$ ) less than that of patients diagnosed prelockdown, presuming care management was equivalent, despite the difference in time period between survival cohort and study cohort. We are aware that this remains an assumption, but one which nonetheless illustrates and anticipates the lockdowns' marked deleterious impact on these patients' health. The full lockdown-related impact on patient survival will of course be determined over a three year survival study.

Regarding patient characteristics, no difference was seen in the groups screened pre- and post-lockdown (Table 1, Suppl. Figure 2-3). The delay of blood sample delivery was also similar, as was the mutant cirDNA concentration, and the mutant allele frequency (Suppl. Figure 4-6, Suppl. Table 1). The white blood cell count, LDH, and CEA median level were slightly higher in the post-lockdown setting, but without the difference being statistically significant (Table 1, Suppl. Figure 7-9). Note, the cirDNA concentration significantly correlates with the LDH and white blood cell count $(r=0.72, p<0.0001$; and $r=0.73, p<0.0001$, respectively) in the postlockdown patients, while the CEA does not (Suppl. Figure 10-14). 
medRxiv preprint doi: https://doi.org/10.1101/2021.03.17.21253408; this version posted March 24, 2021. The copyright holder for this preprint (which was not certified by peer review) is the author/funder, who has granted medRxiv a license to display the preprint in All rights reserved. No reuse allowed without permission.

\section{Discussion:}

In light of the differential in tumor burden between patients diagnosed pre- and postlockdown, and the resulting risk of reduced survival, our data points to the deleterious impact of the lockdown and pandemic-related circumstances on newly diagnosed $\mathrm{mCRC}$ patients who delayed their first visit to an oncologist.

The lower number of diagnoses performed during the COVID-19 crisis $^{1},{ }^{3}$ is undoubtedly due to patients' reluctance to visit a doctor, arising from fears of catching COVID-19 or of burdening the heath system. Take the example of a Australian sixty year-old patient, currently being treated for jaw cancer, who said: "Because I didn't think it was an emergency, I didn't make any moves to go back to see anybody. And also because it was in the middle of COVID I was afraid of getting COVID or giving COVID, and so I just put up with it for a while." ${ }^{\prime 30}$. In addition to patients' subjective anxieties and reticence, there have been numerous reports of significant delays in sending out of millions of solicitations for bowel cancer screening, and of a backlog (in England alone) of thousands of individuals waiting for further investigation after receiving a positive screening result ${ }^{3},{ }^{2}$.

While the lockdown was undoubtedly a necessity, it led to unintended consequences in the diagnosis of various cancers. While the pandemic has dramatically affected all aspects of the cancer care pathway those especially affected are screening, diagnosis and surgical treatment ${ }^{31}, 32,4$. For instance, De Vincentiis et al have reported that the number of cancer diagnoses in Italy decreased by $39 \%$ in the first semester of 2020, compared to the average number recorded in 2018 and 2019. The highest declines in diagnosis were observed in prostate cancer $(75 \%)$, bladder cancer $(66 \%)$, and CRC $(62 \%)$, as determined by comparing the number of new or first metastatic malignant diagnoses during the lockdown (weeks 11-20 of 2020 ) to the same period in the previous two years. Given that colonoscopy numbers are closely related to initial CRC diagnosis, it is interesting to note that there was a $55 \%$ drop in colon exams between March and April of 2020, as reported by "Cancer Australia." In addition to the abrupt drop (86\%) of preventive CRC screenings in the United States following the declaration of the COVID-19 national emergency (March 1, 2020), a drop of 64\% (i.e. 95,000) in the number of colonoscopies performed between March 15 and June 16, 2020, as compared with previous years, has recently been reported ${ }^{33}$. Furthermore, after June 16, weekly volumes remained $36 \%$ lower than pre-COVID-19 levels ${ }^{33}$. With particular relevance to our study, it should be noted that an observational Taiwanese cancer registry study ${ }^{34}$, based on 39,000 newly identified CRC cases, reports that the risk of death increases significantly relative to the delay between diagnosis and treatment: to an interval $\leq 30$ days, for $31-150$ days: HR 1.51; ( $95 \% \mathrm{Cl} 1.43$ to 1.59); for $\geq 151$ days: HR 1.64; (95\% Cl 1.54 to 1.76). The French ONCOCARE-COV study confirmed a reduction in terms of CRC FIT screening (-86\%), CRC biomolecular somatic analyses (-59\%), and new patients files discussed in multidisciplinary tumor board meeting (-39\%) during the 3-month lockdown period in 2020 compared with the same trimester in $2019^{31}$.

Several papers have generated model-based estimates of the clinical consequences of delaying the first visit of newly diagnosed cancer patients ${ }^{26}, 35,36$. In the UK, an even modest delay of three to six months in surgery for cancer is expected to mitigate $19 \%-43 \%$ of the life years gained by hospitalization, as reported by Sud et $\mathrm{al}^{35}$. Recent estimates from Lai et al ${ }^{37}$ 
medRxiv preprint doi: https://doi.org/10.1101/2021.03.17.21253408; this version posted March 24, 2021. The copyright holder for this preprint (which was not certified by peer review) is the author/funder, who has granted medRxiv a license to display the preprint in All rights reserved. No reuse allowed without permission.

predict about 18,000 excess cancer deaths over the next 12 months due to the COVID-19 crisis. Besides the 1 million deaths from breast cancer alone which would have been expected over the next decade in the US, about 10,000 additional deaths are now expected due to pandemicrelated delays of no more than six months in screening and cancer care ${ }^{38}$.

The COVID-19 related lockdowns' effects on the provision of health care were particularly notable in oncology, and the prospect of repeated or extended lockdowns entails the threat of decreased surveillance and advance care planning. To address this, recommendations and guidance for delivering care to cancer patients during the crisis and lockdowns were established by regulatory institutions such as the $\mathrm{ASCO}$ or $\mathrm{ESMO}^{1},{ }^{2}$. In order to minimize risks to patients with gastrointestinal malignancies, for instance, new priorities were set by the American College of Surgeons, the Society of Surgical Oncology, the French digestive oncology intergroup guideline (TNCD), and the ESMO; these included prioritizing surgery for colon cancer involving imminent obstruction, or for locally advanced rectal cancer; similarly, new priorities concerning CRC management were set by the US Colorectal Cancer Alliance, TNCD, NCCN, ESMO, and the City of Hope National Medical Center ${ }^{1}$. Such recommendations were used to reclassify and reprioritize ongoing CRC care and management during the lockdown.

When CRC is diagnosed early, the prognosis for treatment and cure is more favorable. On the basis of a large meta-analysis, Hanna et al. ${ }^{26}$ recently reported that even a four week delay of treatment is associated with increased mortality for seven cancers, in particular CRC (HR, 1.04; $95 \% \mathrm{Cl}$ [0.95-1.13]). Our quantitative observation (albeit performed on a small sample of a specific type of cancer patient) shows that delays in diagnosis would unnecessarily cost lives and life-years. At a time when France and several other European countries are enacting a second lockdown in response to a new proliferation of the virus, we believe that corrective action to the impact on cancer diagnosis should be taken, including (i), reinforcing mass screening using the faecal occult blood test; (ii), increasing the communication strategy needed to avoid late patient diagnosis; and (iii), the provision of adequate resources and robust plans to deal with backlogs in diagnosis and treatment. We speculate that patient triage could be performed based on the quick assessment of tumor burden and the testing of biomarkers with predictive and prognosis value (such as immunohistochemistry for mismatch repair proteins; mutation analysis for KRAS, NRAS, and BRAF). For this purpose, we believe that cirDNA analysis revealing qualitative (tumor molecular profiling) or quantitative information ${ }^{8}, 2021,39,13$ may represent an ideal tool, as previously reported ${ }^{16},{ }^{19}, 40$.

Despite the growing number of reports which highlight the magnitude of the indirect effects of the pandemic on health systems worldwide, no direct evaluation has yet been made regarding the increased tumor burden of newly diagnosed patients post-lockdown. Ours is the first assessment of the impact on diagnostic services related to a specific cancer. It would be premature to envisage a definitive evaluation of the fallout from all delays in diagnosis, screening and treatment, and our exploratory study is offered rather as a snapshot of a situation which continues to evolve. In conclusion, our observation at least point out CRC as a major area for intervention in order to minimize the clinical impact of a diagnostic delay due to COVID-19 crisis. 
medRxiv preprint doi: https://doi.org/10.1101/2021.03.17.21253408; this version posted March 24, 2021. The copyright holder for this preprint (which was not certified by peer review) is the author/funder, who has granted medRxiv a license to display the preprint in All rights reserved. No reuse allowed without permission.

\section{Acknowledgements}

The authors thank the excellent technical assistance of C. Sanchez and A. Kudriatsev, and Cormac Mc Carthy for English editing. We thank also all CRA and clinical co-investigators, $\mathrm{M}$. Bergeaud (Unicancer, Paris), and the support of AMGEN. B. Pastor was partially supported by SIRIC Montpellier Cancer Grant INCa_Inserm_DGOS_12553, and AR Thierry by INSERM.

\section{References}

(1) Richards, M.; Anderson, M.; Carter, P.; Ebert, B. L.; Mossialos, E. The Impact of the COVID-19 Pandemic on Cancer Care. Nat Cancer 2020, 1 (6), 565-567. https://doi.org/10.1038/s43018020-0074-y.

(2) Uzzo, R.G.; Kutinov, A.; Geynisman D.M. Coronavirus disease 2019 (COVID-19): Cancer screening, diagnosis, treatment, and posttreatment surveillance in uninfected patients during the pandemic. Oct. 9, 2020. https://www.uptodate.com/contents/coronavirus-disease-2019covid-19-cancer-screening-diagnosis-treatment-and-posttreatment-surveillance-inuninfected-patients-during-the-pandemic

(3) Greenwood, E.; Swanton, C. Consequences of COVID-19 for Cancer Care - a CRUK Perspective. Nat Rev Clin Oncol 2020. https://doi.org/10.1038/s41571-020-00446-0.

(4) De Vincentiis, L.; Carr, R. A.; Mariani, M. P.; Ferrara, G. Cancer Diagnostic Rates during the 2020 'Lockdown', Due to COVID-19 Pandemic, Compared with the 2018-2019: An Audit Study from Cellular Pathology. J Clin Pathol 2020, jclinpath-2020-206833. https://doi.org/10.1136/jclinpath-2020-206833.

(5) Kaufman, H. W.; Chen, Z.; Niles, J.; Fesko, Y. Changes in the Number of US Patients With Newly Identified Cancer Before and During the Coronavirus Disease 2019 (COVID-19) Pandemic. JAMA Netw Open 2020, 3 (8), e2017267. https://doi.org/10.1001/jamanetworkopen.2020.17267.

(6) Vecchione, L.; Stintzing, S.; Pentheroudakis, G.; Douillard, J.-Y.; Lordick, F. ESMO Management and Treatment Adapted Recommendations in the COVID-19 Era: Colorectal Cancer. ESMO Open 2020, 5 (Suppl 3), e000826. https://doi.org/10.1136/esmoopen-2020-000826.

(7) Thierry, A. R.; El Messaoudi, S.; Gahan, P. B.; Anker, P.; Stroun, M. Origins, Structures, and Functions of Circulating DNA in Oncology. Cancer Metastasis Rev 2016, 35 (3), 347-376. https://doi.org/10.1007/s10555-016-9629-x.

(8) Wan, J. C. M.; Massie, C.; Garcia-Corbacho, J.; Mouliere, F.; Brenton, J. D.; Caldas, C.; Pacey, S.; Baird, R.; Rosenfeld, N. Liquid Biopsies Come of Age: Towards Implementation of Circulating Tumour DNA. Nat Rev Cancer 2017, 17 (4), 223-238. https://doi.org/10.1038/nrc.2017.7.

(9) Diaz, L. A.; Bardelli, A. Liquid Biopsies: Genotyping Circulating Tumor DNA. JCO 2014, 32 (6), 579-586. https://doi.org/10.1200/JCO.2012.45.2011.

(10) Wei, T.; Zhang, Q.; Li, X.; Su, W.; Li, G.; Ma, T.; Gao, S.; Lou, J.; Que, R.; Zheng, L.; Bai, X.; Liang, T. Monitoring Tumor Burden in Response to FOLFIRINOX Chemotherapy Via Profiling Circulating Cell-Free DNA in Pancreatic Cancer. Mol Cancer Ther 2019, 18 (1), 196-203. https://doi.org/10.1158/1535-7163.MCT-17-1298.

(11) Fiala, C.; Diamandis, E. P. Utility of Circulating Tumor DNA in Cancer Diagnostics with Emphasis on Early Detection. BMC Med 2018, 16 (1), 166. https://doi.org/10.1186/s12916-018-1157-9.

(12) Kananen, L.; Hurme, M.; Jylhä, M.; Härkänen, T.; Koskinen, S.; Stenholm, S.; Kähönen, M.; Lehtimäki, T.; Ukkola, O.; Jylhävä, J. Circulating Cell-Free DNA Level Predicts All-Cause Mortality Independent of Other Predictors in the Health 2000 Survey. Sci Rep 2020, 10 (1), 13809. https://doi.org/10.1038/s41598-020-70526-9.

(13) Thierry, A. R.; Pastor, B.; Jiang, Z.-Q.; Katsiampoura, A. D.; Parseghian, C.; Loree, J. M.; Overman, M. J.; Sanchez, C.; Messaoudi, S. E.; Ychou, M.; Kopetz, S. Circulating DNA Demonstrates Convergent Evolution and Common Resistance Mechanisms during Treatment of Colorectal 
medRxiv preprint doi: https://doi.org/10.1101/2021.03.17.21253408; this version posted March 24, 2021. The copyright holder for this preprint (which was not certified by peer review) is the author/funder, who has granted medRxiv a license to display the preprint in perpetuity.

All rights reserved. No reuse allowed without permission.

Cancer. Clin Cancer Res 2017, 23 (16), 4578-4591. https://doi.org/10.1158/1078-0432.CCR-170232.

(14) Saluja, H.; Karapetis, C. S.; Pedersen, S. K.; Young, G. P.; Symonds, E. L. The Use of Circulating Tumor DNA for Prognosis of Gastrointestinal Cancers. Front. Oncol. 2018, 8, 275. https://doi.org/10.3389/fonc.2018.00275.

(15) Xu, X.; Yu, Y.; Shen, M.; Liu, M.; Wu, S.; Liang, L.; Huang, F.; Zhang, C.; Guo, W.; Liu, T. Role of Circulating Free DNA in Evaluating Clinical Tumor Burden and Predicting Survival in Chinese Metastatic Colorectal Cancer Patients. BMC Cancer 2020, 20 (1), 1006. https://doi.org/10.1186/s12885-020-07516-7.

(16) El Messaoudi, S.; Mouliere, F.; Du Manoir, S.; Bascoul-Mollevi, C.; Gillet, B.; Nouaille, M.; Fiess, C.; Crapez, E.; Bibeau, F.; Theillet, C.; Mazard, T.; Pezet, D.; Mathonnet, M.; Ychou, M.; Thierry, A. R. Circulating DNA as a Strong Multimarker Prognostic Tool for Metastatic Colorectal Cancer Patient Management Care. Clinical Cancer Research 2016, 22 (12), 3067-3077. https://doi.org/10.1158/1078-0432.CCR-15-0297.

(17) Barault, L.; Amatu, A.; Siravegna, G.; Ponzetti, A.; Moran, S.; Cassingena, A.; Mussolin, B.; Falcomatà, C.; Binder, A. M.; Cristiano, C.; Oddo, D.; Guarrera, S.; Cancelliere, C.; Bustreo, S.; Bencardino, K.; Maden, S.; Vanzati, A.; Zavattari, P.; Matullo, G.; Truini, M.; Grady, W. M.; Racca, P.; Michels, K. B.; Siena, S.; Esteller, M.; Bardelli, A.; Sartore-Bianchi, A.; Di Nicolantonio, F. Discovery of Methylated Circulating DNA Biomarkers for Comprehensive Non-Invasive Monitoring of Treatment Response in Metastatic Colorectal Cancer. Gut 2018, 67 (11), 19952005. https://doi.org/10.1136/gutjnl-2016-313372.

(18) Spindler, K.-L. G. Methodological, Biological and Clinical Aspects of Circulating Free DNA in Metastatic Colorectal Cancer. Acta Oncologica 2017, 56 (1), 7-16. https://doi.org/10.1080/0284186X.2016.1253861.

(19) Hamfjord, J.; Guren, T. K.; Dajani, O.; Johansen, J. S.; Glimelius, B.; Sorbye, H.; Pfeiffer, P.; Lingjærde, O. C.; Tveit, K. M.; Kure, E. H.; Pallisgaard, N.; Spindler, K.-L. G. Total Circulating CellFree DNA as a Prognostic Biomarker in Metastatic Colorectal Cancer before First-Line Oxaliplatin-Based Chemotherapy. Annals of Oncology 2019, 30 (7), 1088-1095. https://doi.org/10.1093/annonc/mdz139.

(20) Thierry, A. R.; Mouliere, F.; El Messaoudi, S.; Mollevi, C.; Lopez-Crapez, E.; Rolet, F.; Gillet, B.; Gongora, C.; Dechelotte, P.; Robert, B.; Del Rio, M.; Lamy, P.-J.; Bibeau, F.; Nouaille, M.; Loriot, V.; Jarrousse, A.-S.; Molina, F.; Mathonnet, M.; Pezet, D.; Ychou, M. Clinical Validation of the Detection of KRAS and BRAF Mutations from Circulating Tumor DNA. Nat Med 2014, 20 (4), 430-435. https://doi.org/10.1038/nm.3511.

(21) Thierry, A. R.; El Messaoudi, S.; Mollevi, C.; Raoul, J. L.; Guimbaud, R.; Pezet, D.; Artru, P.; Assenat, E.; Borg, C.; Mathonnet, M.; De La Fouchardière, C.; Bouché, O.; Gavoille, C.; Fiess, C.; Auzemery, B.; Meddeb, R.; Lopez-Crapez, E.; Sanchez, C.; Pastor, B.; Ychou, M. Clinical Utility of Circulating DNA Analysis for Rapid Detection of Actionable Mutations to Select Metastatic Colorectal Patients for Anti-EGFR Treatment. Annals of Oncology 2017, 28 (9), 2149-2159. https://doi.org/10.1093/annonc/mdx330.

(22) Chibaudel, B.; Bonnetain, F.; Tournigand, C.; Bengrine-Lefevre, L.; Teixeira, L.; Artru, P.; Desramé, J.; Larsen, A. K.; André, T.; Louvet, C.; Gramont, A. Simplified Prognostic Model in Patients with Oxaliplatin-Based or Irinotecan-Based First-Line Chemotherapy for Metastatic Colorectal Cancer: A GERCOR Study. The Oncologist 2011, 16 (9), 1228-1238. https://doi.org/10.1634/theoncologist.2011-0039.

(23) Goey, K. K. H.; Mahmoud, R.; Sørbye, H.; Glimelius, B.; Köhne, C.-H.; Sargent, D. J.; Punt, C. J. A.; van Oijen, M. G. H.; Koopman, M. Reporting of Patient Characteristics and Stratification Factors in Phase 3 Trials Investigating First-Line Systemic Treatment of Metastatic Colorectal Cancer: A Systematic Review. European Journal of Cancer 2018, 96, 115-124. https://doi.org/10.1016/j.ejca.2018.03.026. 
medRxiv preprint doi: https://doi.org/10.1101/2021.03.17.21253408; this version posted March 24, 2021. The copyright holder for this preprint (which was not certified by peer review) is the author/funder, who has granted medRxiv a license to display the preprint in

All rights reserved. No reuse allowed without permission.

(24) Meddeb, R.; Pisareva, E.; Thierry, A. R. Guidelines for the Preanalytical Conditions for Analyzing Circulating Cell-Free DNA. Clinical Chemistry 2019, 65 (5), 623-633. https://doi.org/10.1373/clinchem.2018.298323.

(25) Mouliere, F.; El Messaoudi, S.; Pang, D.; Dritschilo, A.; Thierry, A. R. Multi-Marker Analysis of Circulating Cell-Free DNA toward Personalized Medicine for Colorectal Cancer. Molecular Oncology 2014, 8 (5), 927-941. https://doi.org/10.1016/j.molonc.2014.02.005.

(26) Hanna, T. P.; King, W. D.; Thibodeau, S.; Jalink, M.; Paulin, G. A.; Harvey-Jones, E.; O’Sullivan, D. E.; Booth, C. M.; Sullivan, R.; Aggarwal, A. Mortality Due to Cancer Treatment Delay: Systematic Review and Meta-Analysis. BMJ 2020, m4087. https://doi.org/10.1136/bmj.m4087.

(27) Weitz, J.; Koch, M.; Debus, J.; Höhler, T.; Galle, P. R.; Büchler, M. W. Colorectal Cancer. The Lancet 2005, 365 (9454), 153-165. https://doi.org/10.1016/S0140-6736(05)17706-X.

(28) Yan, Q.; Zhang, K.; Guo, K.; Liu, S.; Wasan, H. S.; Jin, H.; Yuan, L.; Feng, G.; Shen, F.; Shen, M.; Ma, S.; Ruan, S. Value of Tumor Size as a Prognostic Factor in Metastatic Colorectal Cancer Patients after Chemotherapy: A Population-Based Study. Future Oncology 2019, 15 (15), 17451758. https://doi.org/10.2217/fon-2018-0785.

(29) Giessen, C.; Laubender, R. P.; Ankerst, D. P.; Stintzing, S.; Modest, D. P.; Mansmann, U.; Heinemann, V. Progression-Free Survival as a Surrogate Endpoint for Median Overall Survival in Metastatic Colorectal Cancer: Literature-Based Analysis from 50 Randomized First-Line Trials. Clinical Cancer Research 2013, 19 (1), 225-235. https://doi.org/10.1158/1078-0432.CCR-121515.

(30) Daly N. Cancer tests and operations dropped up to 50 per cent during April lockdown, data shows. 13 Sept, 2020. https://www.abc.net.au/news/2020-09-14/cancer-tests-operationsdrop-up-to-50-per-cent-april-coronavirus/12622396.

(31) Brugel, M.; Carlier, C.; Essner, C.; Debreuve-Theresette, A.; Beck, M.; Merrouche, Y.; Bouché, O. Dramatic Changes in Oncology Care Pathways During the COVID -19 Pandemic: The French ONCOCARE-COV Study. The Oncol 2020, onco.13578. https://doi.org/10.1002/onco.13578.

(32) Dinmohamed, A. G.; Visser, O.; Verhoeven, R. H. A.; Louwman, M. W. J.; van Nederveen, F. H.; Willems, S. M.; Merkx, M. A. W.; Lemmens, V. E. P. P.; Nagtegaal, I. D.; Siesling, S. Fewer Cancer Diagnoses during the COVID-19 Epidemic in the Netherlands. The Lancet Oncology 2020, 21 (6), 750-751. https://doi.org/10.1016/S1470-2045(20)30265-5.

(33) Desai, A.; Warner, J.; Kuderer, N.; Thompson, M.; Painter, C.; Lyman, G.; Lopes, G. Crowdsourcing a Crisis Response for COVID-19 in Oncology. Nat Cancer 2020, 1 (5), 473-476. https://doi.org/10.1038/s43018-020-0065-z.

(34) Lee, S. Y.; Lei, B.; Mallick, B. Estimation of COVID-19 Spread Curves Integrating Global Data and Borrowing Information. PLOS ONE 2020, $15 \quad$ (7), e0236860. https://doi.org/10.1371/journal.pone.0236860.

(35) Sud, A.; Torr, B.; Jones, M. E.; Broggio, J.; Scott, S.; Loveday, C.; Garrett, A.; Gronthoud, F.; Nicol, D. L.; Jhanji, S.; Boyce, S. A.; Williams, M.; Riboli, E.; Muller, D. C.; Kipps, E.; Larkin, J.; Navani, N.; Swanton, C.; Lyratzopoulos, G.; McFerran, E.; Lawler, M.; Houlston, R.; Turnbull, C. Effect of Delays in the 2-Week-Wait Cancer Referral Pathway during the COVID-19 Pandemic on Cancer Survival in the UK: A Modelling Study. The Lancet Oncology 2020, 21 (8), 1035-1044. https://doi.org/10.1016/S1470-2045(20)30392-2.

(36) Maringe, C.; Spicer, J.; Morris, M.; Purushotham, A.; Nolte, E.; Sullivan, R.; Rachet, B.; Aggarwal, A. The Impact of the COVID-19 Pandemic on Cancer Deaths Due to Delays in Diagnosis in England, UK: A National, Population-Based, Modelling Study. The Lancet Oncology 2020, 21 (8), 1023-1034. https://doi.org/10.1016/S1470-2045(20)30388-0.

(37) Lai, A. G.; Pasea, L.; Banerjee, A.; Hall, G.; Denaxas, S.; Chang, W. H.; Katsoulis, M.; Williams, B.; Pillay, D.; Noursadeghi, M.; Linch, D.; Hughes, D.; Forster, M. D.; Turnbull, C.; Fitzpatrick, N. K.; Boyd, K.; Foster, G. R.; Enver, T.; Nafilyan, V.; Humberstone, B.; Neal, R. D.; Cooper, M.; Jones, M.; Pritchard-Jones, K.; Sullivan, R.; Davie, C.; Lawler, M.; Hemingway, H. Estimated Impact of the COVID-19 Pandemic on Cancer Services and Excess 1-Year Mortality in People with Cancer and Multimorbidity: Near Real-Time Data on Cancer Care, Cancer Deaths and a Population- 
medRxiv preprint doi: https://doi.org/10.1101/2021.03.17.21253408; this version posted March 24, 2021. The copyright holder for this preprint (which was not certified by peer review) is the author/funder, who has granted medRxiv a license to display the preprint in All rights reserved. No reuse allowed without permission.

Based Cohort Study. BMJ Open 2020, 10 (11), e043828. https://doi.org/10.1136/bmjopen2020-043828.

(38) Sharpless, N. E. COVID-19 and Cancer. Science 2020, 368 (6497), 1290-1290. https://doi.org/10.1126/science.abd3377.

(39) Meddeb, R.; Dache, Z. A. A.; Thezenas, S.; Otandault, A.; Tanos, R.; Pastor, B.; Sanchez, C.; Azzi, J.; Tousch, G.; Azan, S.; Mollevi, C.; Adenis, A.; El Messaoudi, S.; Blache, P.; Thierry, A. R. Quantifying Circulating Cell-Free DNA in Humans. Sci Rep 2019, 9 (1), 5220. https://doi.org/10.1038/s41598-019-41593-4.

(40) Sundquist, K.; Sundquist, J.; Hedelius, A.; Memon, A. A. Diagnostic Potential of Circulating Cellfree Nuclear and Mitochondrial DNA for Several Cancer Types and Nonmalignant Diseases: A Study on Suspected Cancer Patients. Molecular Carcinogenesis 2020, 59 (12), 1362-1370. https://doi.org/10.1002/mc.23261. 
medRxiv preprint doi: https://doi.org/10.1101/2021.03.17.21253408; this version posted March 24, 2021. The copyright holder for this preprint (which was not certified by peer review) is the author/funder, who has granted medRxiv a license to display the preprint in

All rights reserved. No reuse allowed without permission.

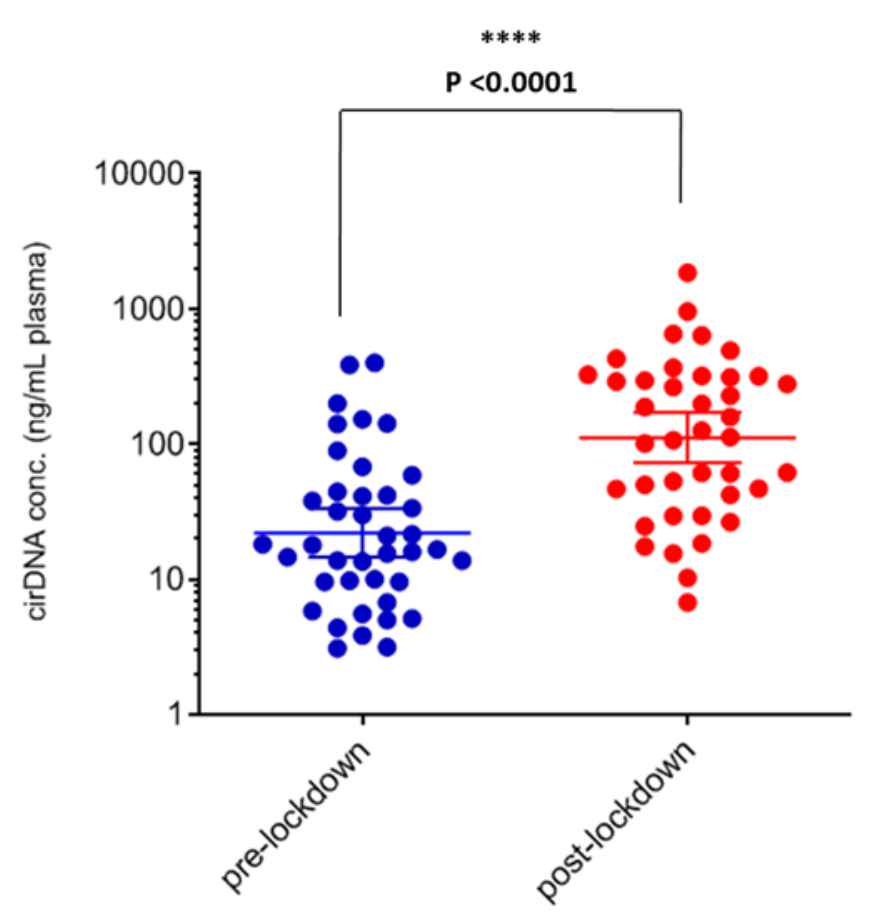

Figure 1: Comparison of cirDNA concentration in newly diagnosed $\mathrm{mCRC}$ patients from the pre- and post-lockdown study cohorts. Group median is represented by a horizontal bold bar. Mann-Whitney U test was performed to compare these distributions, and revealed a significant difference between preand post-lockdown patients (with p-value<0.0001). Each dot (blue, pre-lockdown; red, post-lockdown) represents the values of a single patient. 
medRxiv preprint doi: https://doi.org/10.1101/2021.03.17.21253408; this version posted March 24, 2021. The copyright holder for this preprint (which was not certified by peer review) is the author/funder, who has granted medRxiv a license to display the preprint in perpetuity.

All rights reserved. No reuse allowed without permission.

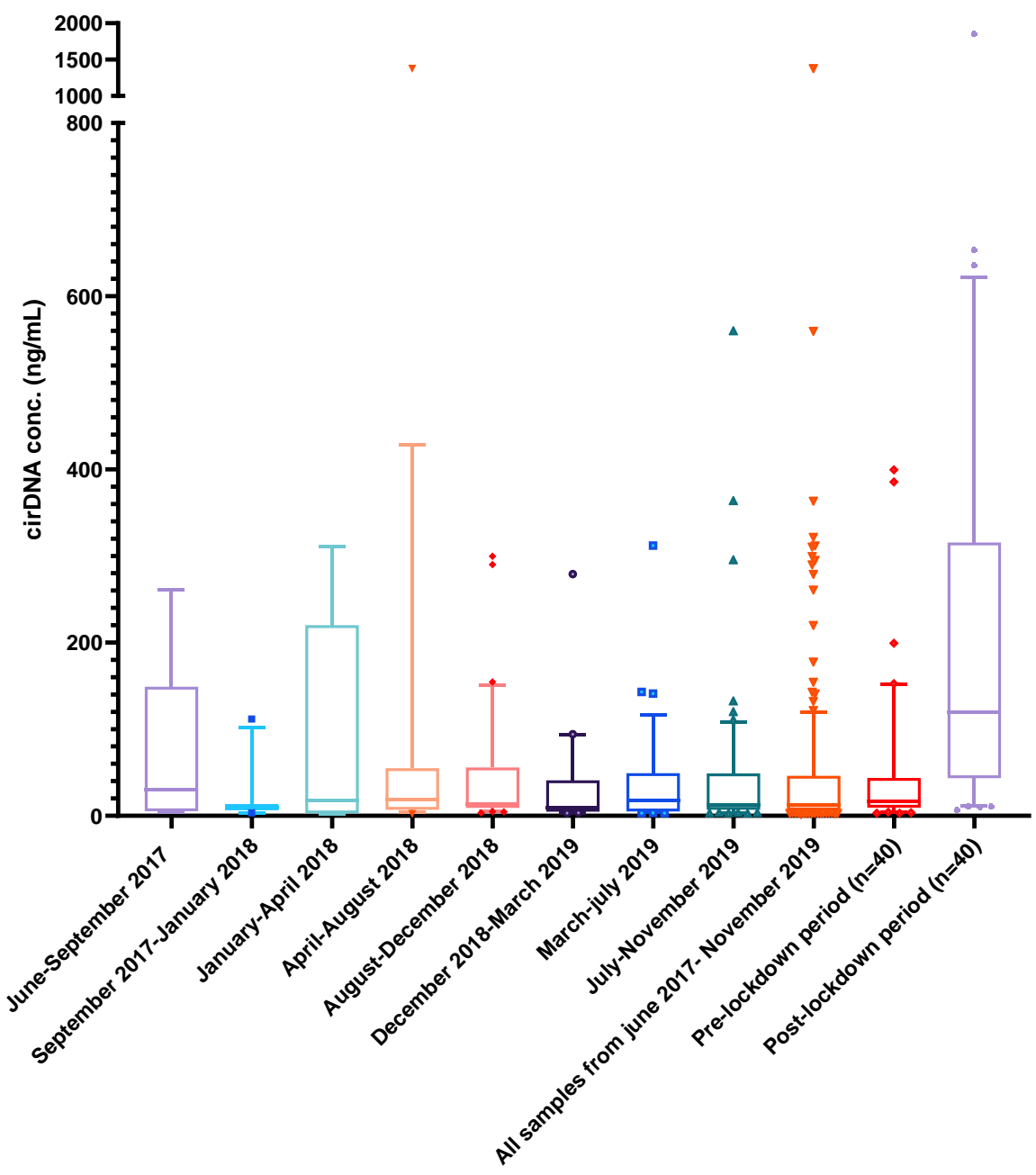

\begin{tabular}{|c|c|c|c|c|c|}
\hline Cohort ID & $\begin{array}{l}\text { Fractional } 110 \text { days } \\
\text { screening period }\end{array}$ & $\begin{array}{c}\text { Cohort size } \\
\text { (n) }\end{array}$ & $\begin{array}{l}\text { CirDNA median conc. } \\
\text { (ng/mL plasma) }\end{array}$ & $\begin{array}{l}\text { p value } \\
\text { vs. pre- } \\
\text { lockdown } \\
\text { cohort }\end{array}$ & $\begin{array}{c}\text { p value } \\
\text { vs. post- } \\
\text { lockdown } \\
\text { cohort }\end{array}$ \\
\hline post-lockdown period & $05 / 14 / 20$ to $09 / 03 / 20$ & 40 & 119,2 & & \\
\hline pre-lockdown period & $11 / 25 / 19$ to $03 / 09 / 20$ & 40 & 17,27 & , & $<0,0001$ \\
\hline All samples: June 2017-November 2019 & $06 / 28 / 17$ to $11 / 24 / 19$ & 188 & 12,98 & 0,349 & $<0,0001$ \\
\hline July-November 2019 & $07 / 16 / 19$ to $11 / 24 / 19$ & 60 & 12,91 & 0,3973 & $<0,0001$ \\
\hline March-July 2019 & $03 / 06 / 19$ to $07 / 15 / 19$ & 38 & 18,38 & 0,5358 & $<0,0001$ \\
\hline December 2018-March 2019 & $12 / 26 / 18$ to $03 / 05 / 19$ & 20 & 9,19 & 0,2732 & $<0,0001$ \\
\hline August-December 2018 & $08 / 16 / 18$ to $12 / 25 / 18$ & 30 & 13,38 & 0,8898 & $<0,0001$ \\
\hline April-August 2018 & $04 / 06 / 18$ to $08 / 15 / 18$ & 18 & 18,51 & 0,9904 & 0,0006 \\
\hline January-April 2018 & $01 / 26 / 18$ to $04 / 05 / 18$ & 7 & 18,36 & 0,7118 & 0,0304 \\
\hline Semptember 2017-January 2018 & $09 / 16 / 17$ to $01 / 25 / 18$ & 10 & 9,13 & 0,066 & $<0,0001$ \\
\hline June-September 2017 & $06 / 28 / 17$ to $09 / 15 / 17$ & 5 & 29,94 & $>0,9999$ & 0,0385 \\
\hline
\end{tabular}

Figure 2: Comparison of study cohort of fractional 110 day period groups of patients initially screened from the start of the PANIRINOX study with the pre-lockdown study cohort. Top, box plot representation of cirDNA concentration values according to fractional 110 day period groups, pre- and post-lockdown study cohorts. Mann-Whitney $U$ test was performed to compare distribution. Bottom, description of the fractional 110 day period groups of patients, and statistical characterization of the difference of median cirDNA concentration as determined in the post-lockdown study cohort and the fractional 110 day period groups of patients. 
medRxiv preprint doi: https://doi.org/10.1101/2021.03.17.21253408; this version posted March 24, 2021. The copyright holder for this preprint (which was not certified by peer review) is the author/funder, who has granted medRxiv a license to display the preprint in

All rights reserved. No reuse allowed without permission.

A

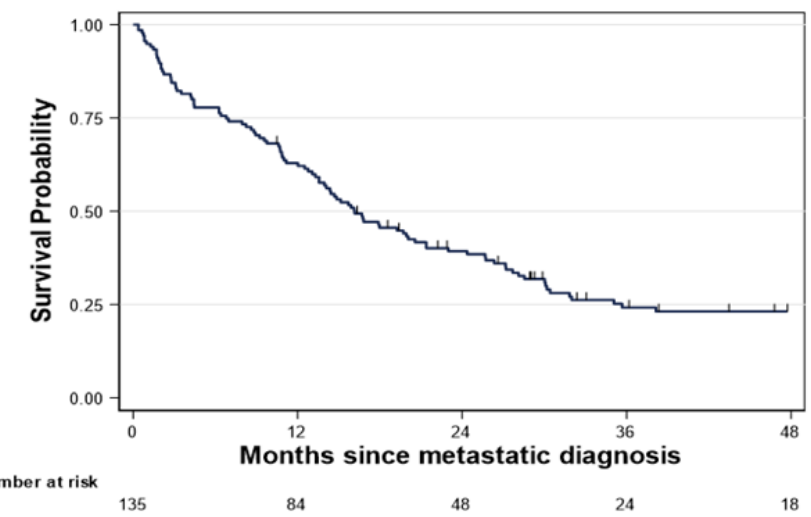

B

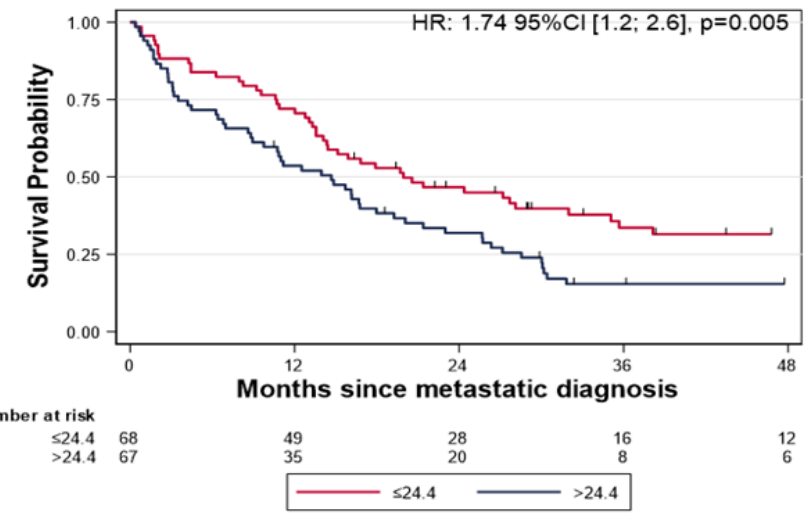

C

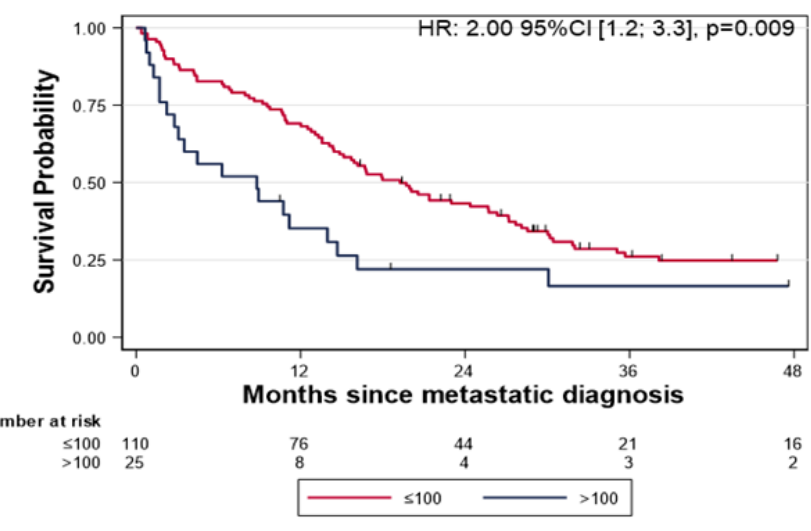

Figure 3: Overall survival analysis on the retrospective cohort of newly diagnosed $m C R C$ patients. A, Kaplan-Meier survival curve on the full cohort $(\mathrm{N}=135)$. B, Kaplan-Meier survival curve and log-rank test according to cirDNA concentrations dichotomized around the median $(24.4 \mathrm{ng} / \mathrm{mL})$. C, KaplanMeier survival curve and log-rank test according to cirDNA concentrations dichotomized around the median $(100 \mathrm{ng} / \mathrm{mL})$. 
medRxiv preprint doi: https://doi.org/10.1101/2021.03.17.21253408; this version posted March 24, 2021. The copyright holder for this preprint (which was not certified by peer review) is the author/funder, who has granted medRxiv a license to display the preprint in perpetuity.

All rights reserved. No reuse allowed without permission.

Table 1. Patients characteristics

\begin{tabular}{|c|c|c|c|c|}
\hline & \multicolumn{3}{|c|}{ Cohorts N (\%) } & \multirow[b]{2}{*}{$P$ value } \\
\hline & PaniCov & Pre-lockdown & Post-lockdown & \\
\hline $\mathbf{N}$ & $80(100 \%)$ & $40(50 \%)$ & $40(50 \%)$ & \\
\hline Age & & & & 0,856 \\
\hline Median (range) & $62(37-77)$ & $63(37-77)$ & $61(39-77)$ & \\
\hline missing & 1 & 0 & 1 & \\
\hline Gender & & & & 0,648 \\
\hline Male & $48(60.0 \%)$ & $25(62.5 \%)$ & $23(57.5 \%)$ & \\
\hline Female & $32(40.0 \%)$ & $15(37.5 \%)$ & $17(42.5 \%)$ & \\
\hline Location of primary tumour & & & & 0,842 \\
\hline Right colon & $19(24.0 \%)$ & $9(23.1 \%)$ & $10(25.0 \%)$ & \\
\hline Left colon & $60(76.0 \%)$ & $30(76.9 \%)$ & $30(75.0 \%)$ & \\
\hline missing & 1 & 1 & 0 & \\
\hline Primary tumor in place & & & & 0,805 \\
\hline Yes & $57(71.25 \%)$ & $28(70.0 \%)$ & $29(72.5 \%)$ & \\
\hline No & $23(28.75 \%)$ & $12(30.0 \%)$ & $11(27.5 \%)$ & \\
\hline \multicolumn{5}{|l|}{ Number of metastatic sites } \\
\hline Median (range) & $2(1-4)$ & $2(1-3)$ & $2(1-4)$ & 0,304 \\
\hline 1 & $28(43.8 \%)$ & $15(48.4 \%)$ & $13(39.4 \%)$ & 0460 \\
\hline$>1$ & $36(56.3 \%)$ & $16(51.6 \%)$ & $20(60.6 \%)$ & 0,469 \\
\hline missing & 16 & 9 & 7 & \\
\hline Liver involvement & & & & 0,958 \\
\hline Yes & $55(84.6 \%)$ & $27(84.4 \%)$ & $28(84.9 \%)$ & \\
\hline No & $10(15.4 \%)$ & $5(15.6 \%)$ & $5(15.1 \%)$ & \\
\hline missing & 15 & 8 & 7 & \\
\hline Limited liver disease & & & & 0,805 \\
\hline Yes & $23(28.75 \%)$ & $12(30.0 \%)$ & $11(27.5 \%)$ & \\
\hline No & $57(71.25 \%)$ & $28(70.0 \%)$ & $29(72.5 \%)$ & \\
\hline \multicolumn{5}{|l|}{ LDH level (U/L) } \\
\hline Median (range) & $345(137-2690)$ & $263(148-2690)$ & $410(137-1256)$ & 0,456 \\
\hline$<245$ & $22(39.3 \%)$ & $14(48.3 \%)$ & $8(29.6 \%)$ & 0180 \\
\hline$\geq 245$ & $34(60.7 \%)$ & $15(51.7 \%)$ & $19(70.4 \%)$ & 0,180 \\
\hline missing & 24 & 11 & 13 & \\
\hline \multicolumn{5}{|l|}{ White blood cell count (G/L) } \\
\hline Median (range) & $9.1(4.4-27.3)$ & $8.5(4.8-22.4)$ & $9.4(4.4-27.3)$ & 0,309 \\
\hline$<10$ & $38(62.3 \%)$ & $21(67.7 \%)$ & $17(56.7 \%)$ & 0372 \\
\hline$\geq 10$ & $23(37.7 \%)$ & $10(32.3 \%)$ & $13(43.3 \%)$ & 0,372 \\
\hline missing & 19 & 9 & 10 & \\
\hline \multicolumn{5}{|l|}{ CEA level (ng/mL) } \\
\hline Median (range) & $39.8(0.7-13590)$ & $34.0(0.7-9902)$ & $40.8(1.4-13590)$ & 0,489 \\
\hline$<5$ & $9(14.8 \%)$ & $4(12.9 \%)$ & $5(16.7 \%)$ & 0679 \\
\hline$\geq 5$ & $52(85.2 \%)$ & $27(87.1 \%)$ & $25(83.3 \%)$ & $0,6 / 9$ \\
\hline missing & 19 & 9 & 10 & \\
\hline
\end{tabular}


medRxiv preprint doi: https://doi.org/10.1101/2021.03.17.21253408; this version posted March 24, 2021. The copyright holder for this preprint (which was not certified by peer review) is the author/funder, who has granted medRxiv a license to display the preprint in All rights reserved. No reuse allowed without permission.

\section{Supplementary Information}

\section{Materials and methods:}

\section{PANIRINOX general information}

Groupe UNICANCER Tumor Group: UCGI; Protocol n: UC-0110/1608; EudraCT n: 2016-001490-33 INDICATION: RAS and B-RAF wild-type metastatic colorectal cancer. RAS and B-RAF mutation will be determined using cirDNA by IntPlex method.

METHODOLOGY: National trial, multicenter, randomized, phase $\|$ assessing combination chemotherapy with fluorouracil, leucovorin, oxaliplatin and panitumumab \pm irinotecan (FOLFOX + panitumumab vs FOLFIRINOX + panitumumab) in metastatic colorectal cancer patients selected by RAS and $B-R A F$ status from cirDNA analysis.

PRIMARY OBJECTIVE: Evaluation of complete response rate of treatment combining FOLFIRINOX and panitumumab.

\section{SECONDARY OBJECTIVE(S):}

- Overall Survival

- Progression free survival

- Secondary resection

- Early tumor shrinkage (ETS)

- Depth of response (DpR)

- Safety profile (NCI CTCAE v 4.03 classification)

- Diagnostic performance of ccfDNA analysis compared to the tumor-tissue analysis (current gold standard).

INCLUSION CRITERIA:

1. Age between 18 and 75 years

2. ECOG PS between 0 and 1

3. Histologically confirmed adenocarcinoma of the colon or rectum

4. Untreated synchronous or metachronous metastatic disease deemed unresectable with curative intent

5. K-Ras (codons 12, 13, 59, 61, 117, 146), N-Ras (codons 12, 13, 59, 61) and B-Raf (codon 600) wildtype tumor status according to plasma analysis of circulating cell free DNA by Intplex technology

6. Measurable disease according to RECIST version 1.1

7. Adequate hematologic, hepatic and renal functions:

- Absolute neutrophil count (ANC) $\geq 2 \times 109 / \mathrm{L}$

- Haemoglobin $\geq 9 \mathrm{~g} / \mathrm{dL}$

- Platelets (PTL) $\geq 100 \times 109 / \mathrm{L}$

- AST/ALT $\leq 5 \times$ ULN

- Alkaline phosphatase $\leq 2.5 \times$ ULN

- Bilirubin $\leq 1.5 \times$ ULN

- Creatinine clearance $\geq 50 \mathrm{~mL} / \mathrm{min}$ (Cockcroft and Gault formula)

8. Life expectancy of at least 3 months

9. Adequate contraception if applicable

10. Patient affiliated to a social security regimen 
medRxiv preprint doi: https://doi.org/10.1101/2021.03.17.21253408; this version posted March 24, 2021. The copyright holder for this preprint (which was not certified by peer review) is the author/funder, who has granted medRxiv a license to display the preprint in All rights reserved. No reuse allowed without permission.

11. Patient information and signed written consent form

12. Uracilemia $<16 \mathrm{ng} / \mathrm{ml}$

NON INCLUSION CRITERIA:

1. History of other malignancy within the previous 5 years (except for appropriately treated insitu cervix carcinoma and non-melanoma skin carcinoma)

2. Adjuvant treatment with oxaliplatin

3. Previous treatment for metastatic disease

4. Patients who received any chemo- and/or radiotherapy within 15 days from the date of blood sampling for the RAS and BRAF test

5. Brain metastases

6. Patients with a history of severe or life-threatening hypersensitivity to the active substances or to any of the excipients delivered in this study

7. Patients with history of pulmonary fibrosis or interstitial pneumonitis

8. Previous organ transplantation, HIV or other immunodeficiency syndromes

9. Concomitant medications/comorbidities that may prevent the patient from receiving study treatment as uncontrolled intercurrent illness (for instance: active infection, active inflammatory disorders, inflammatory bowel disease, intestinal obstruction, symptomatic congestive heart failure, uncontrolled hypertension...)

10. Persistent peripheral neuropathy >grade1 ( $\mathrm{NCl} \mathrm{CT} \mathrm{v4.03)}$

11. Ionic disorders as:

- Kalemia $\leq 1 \times$ LLN

- Magnesemia $<0.5 \mathrm{mmol} / \mathrm{L}$

- Calcemia $<2 \mathrm{mmol} / \mathrm{L}$

12. Patient with known dihydropyrimidine dehydrogenase deficiency

13. QT/QTc $>450 \mathrm{msec}$ for men and $>470 \mathrm{msec}$ for women

14. Patient with contraindication for trial drugs

15. Concomitant intake of St. John's wort

16. Other concomitant cancer

17. Participation in another therapeutic trial

18. Pregnant woman or lactating woman

19. Patients with psychological, familial, sociological or geographical condition hampering compliance with the study protocol and follow-up schedule

20. Legal incapacity or limited legal capacity

\section{CirDNA analysis}

All blood samples were collected in 10-milliter $(\mathrm{mL})$ Streck tubes in all 27 clinical centers that sent by express mail the day or the day after blood draw following strict procedural guidelines. The IRCM U1094/ INSERM laboratory received blood samples within 5 days post-blood draw and centralized all following procedures towards cirDNA analysis under stringent pre-analytical guidelines reported by the laboratory ${ }^{24}$. The blood was then centrifuged at $1,200 \mathrm{~g}$ at $4^{\circ} \mathrm{C}$ for 10 minutes. The supernatants were isolated in sterile $1.5 \mathrm{~mL}$ Eppendorf tubes and centrifuged at $16,000 \mathrm{~g}$ at $4^{\circ} \mathrm{C}$ for 10 minutes. Afterwards, the plasma was either immediately used for DNA extraction or stored at $-20^{\circ} \mathrm{C}$. CirDNA was extracted from $1 \mathrm{~mL}$ of plasma using the QIAmp DNA Mini Blood kit (Qiagen) according to the "Blood and body fluid protocol." DNA extracts were kept at $-20^{\circ} \mathrm{C}$ until used ${ }^{25}$.

The PANIRINOX clinical study implies the use of the IntPlex methodology to select patients showing WT mutational status for KRAS, NRAS and BRAF genes. IntPlex was established by our team and is based on an allele-specific blocker Q-PCR-based method specific for cirDNA analysis to enable the 
medRxiv preprint doi: https://doi.org/10.1101/2021.03.17.21253408; this version posted March 24, 2021. The copyright holder for this preprint (which was not certified by peer review) is the author/funder, who has granted medRxiv a license to display the preprint in All rights reserved. No reuse allowed without permission.

detection of point mutation and to determine mutant allele concentration ${ }^{20}$. This method combined the use of (1) allele-specific Q-PCR with blocking 3'-phosphate-modified oligonucleotide; (2) low Tm primers with mutation in $3^{\prime} ;(3)$ an integrated primer design; (4) routine internal positive and negative controls, and (5) optimal analytical procedures. This method enables the determination of the presence of a mutation, as well as the total concentration of cirDNA, the concentration of mutant cirDNA, the mutant allele frequency, and an index of DNA integrity. Note, the total cirDNA concentration value is determined by targeting a KRAS WT sequence, and is internally controlled by targeting a BRAF WT sequence for each sample ${ }^{25}$.

CirDNA quantification methodology and the data description were carried out according to the MIQE guidelines ${ }^{20}$. Q-PCR amplifications were carried out at least in triplicate in a $25-\mu \mathrm{l}$ reaction volume on CFX96 thermocycler (Bio-Rad) using the Bio-Rad CFX manager. Each PCR mixture was composed of $12.5 \mu \mathrm{l}$ of PCR mix (Bio-Rad Supermix SYBR Green), $2.5 \mu \mathrm{l}$ of each amplification primer $(0.3 \mathrm{pmol} / \mu \mathrm{l})$, $2.5 \mu \mathrm{l}$ of PCR-analyzed water, and $5 \mu \mathrm{l}$ of DNA extract. Thermal cycling consisted of three repeated steps: a 3-minute hot-start polymerase activation-denaturation step at $95^{\circ} \mathrm{C}$ followed by 40 repeated cycles at $95^{\circ} \mathrm{C}$ for 10 seconds and then at $60^{\circ} \mathrm{C}$ for 30 seconds. Melting curves were obtained by increasing the temperature from 55 to $90^{\circ} \mathrm{C}$ with a plate reading every $0.2^{\circ} \mathrm{C}$.

In the PANIRINOX study, 28 different mutations on the KRAS, BRAF and NRAS genes actionable in $\mathrm{mCRC}$ management care are tested. The IntPlex assay is clinically validated ${ }^{20},{ }^{21}$, and shows the highest sensitivity and specificity so far described ${ }^{8}$. Poisson law experiments demonstrated that this method could accurately detect down to one molecule per PCR reaction mixture ${ }^{21}$, with detection sensitivity as high as $1 / 100,000$.

Intra- and inter-reproducibility experiments combining pre-analytic and analytic procedures demonstrated that the coefficient of variation for cirDNA concentration measurement is $24 \%{ }^{25}$. IntPlex has been validated in two clinical studies ${ }^{20},{ }^{21}$ is currently involved in 9 others, and has already enabled the testing of more than 2,000 individuals and 4,500 plama samples.

\section{Statistics}

Statistical analysis of pre- versus post-lockdown data was performed using the GraphPad Prism V6.01 software and survival analysis with STATA 16.0 software. Where appropriate, data were log transformed prior to statistical analysis. Continuous variables were compared using the Mann-Whitney test. Categorical variables were compared using the Pearson's chi-square test. Median follow-up was calculated using the reverse Kaplan-Meier method. Overall survival (OS) was estimated using the Kaplan-Meier method, and compared using the Log-rank test. OS was defined as the time between the date of first metastatic diagnosis and the date of death from any cause. Hazard ratios (HR) are given with their $95 \%$ confidence interval $(95 \% \mathrm{Cl})$. Correlation analysis were performed using the spearman test. A probability of less than 0.05 was considered to be statistically significant; ${ }^{*} p<0.05,{ }^{* *} p<0.01$; $* * * p<0.001 ; * * * * p<0.0001$ 
medRxiv preprint doi: https://doi.org/10.1101/2021.03.17.21253408; this version posted March 24, 2021. The copyright holder for this preprint (which was not certified by peer review) is the author/funder, who has granted medRxiv a license to display the preprint in All rights reserved. No reuse allowed without permission.

\section{Supplementary figures}

\section{Supplementary figure legends:}

Suppl. Figure 1: Illustration of the correlation between the tumor burden and total cirDNA level in three metachronous $\mathrm{mCRC}$ patients (one site) with increasing hepatic tumor mass as determined by MRI (adapted from our previous report: El Messaoudi et al, Clinical Cancer Research, 2013, ref \#16).

Suppl. Figure 2: Comparison of the age of the newly diagnosed $\mathrm{mCRC}$ patients from the pre- and postlockdown study cohorts $(\mathrm{N}=80$ ). Group median is represented by a horizontal bold bar. Mann-Whitney $\mathrm{U}$ test was performed to compare distribution in pre- and post-lockdown patients. Each dot (blue, prelockdown; red, post-lockdown) represents the values of a single patient.

Suppl. Figure 3: Comparison of the gender of the newly diagnosed mCRC patients from the pre- and post-lockdown study cohorts $(\mathrm{N}=80)$.

Suppl. Figure 4: Comparison of the delivery delay of blood samples from the newly diagnosed mCRC patients from the pre- and post-lockdown study cohorts. Mann-Whitney $U$ test was performed to compare distribution in pre- and post-lockdown patients. Each dot (blue, pre-lockdown; red, postlockdown) represents the values of a single patient.

Suppl. Figure 5: Comparison of the mutant cirDNA concentration in the newly mutant diagnosed mCRC patients from pre- and post-lockdown study cohorts $(\mathrm{N}=48)$. Group median is represented by a horizontal bold bar. Mann-Whitney $U$ test was performed to compare distribution in pre- and postlockdown patients. Each dot (blue, pre-lockdown; red, post-lockdown) represents the values of a single patient.

Suppl. Figure 6: Comparison of the mutant allele frequency in the newly diagnosed mutant mCRC patients from the pre- and post-lockdown study cohort ( $\mathrm{N}=48)$. Group median is represented by a horizontal bold bar. Mann-Whitney $U$ test was performed to compare distribution in pre- and postlockdown patients. Each dot (blue, pre-lockdown; red, post-lockdown) represents the values of a single patient.

Suppl. Figure 7: Comparison of the Lactate dehydrogenase (LDH) of the newly diagnosed mCRC patients from the pre- and post-lockdown study cohorts $(\mathrm{N}=56)$. Group median is represented by a horizontal bold dotted line; violin representation. Mann-Whitney $U$ test was performed to compare distribution in pre- and post-lockdown patients. Each dot (blue, pre-lockdown; red, post-lockdown) represents the values of a single patient.

Suppl. Figure 8: Comparison of the white blood cell count in the newly diagnosed $\mathrm{mCRC}$ patients from the pre- and post-lockdown study cohorts $(\mathrm{N}=61)$. Group median is represented by a horizontal bold dotted line; violin representation. Mann-Whitney $U$ test was performed to compare distribution in preand post-lockdown patients. Each dot (blue, pre-lockdown; red, post-lockdown) represents the values of a single patient.

Suppl. Figure 9: Comparison of the carcinoembryonic antigen (CEA) in the newly diagnosed mCRC patients from the pre- and post-lockdown study cohorts $(\mathrm{N}=61)$. Group median is represented by a horizontal bold dotted line; violin representation. Mann-Whitney $U$ test was performed to compare 
medRxiv preprint doi: https://doi.org/10.1101/2021.03.17.21253408; this version posted March 24, 2021. The copyright holder for this preprint (which was not certified by peer review) is the author/funder, who has granted medRxiv a license to display the preprint in All rights reserved. No reuse allowed without permission.

distribution in pre- and post-lockdown patients. Each dot (blue, pre-lockdown; red, post-lockdown) represents the values of a single patient.

Suppl. Figure 10: Pearson $r$ correlation analysis of the cirDNA, LDH, white blood cell count, and CEA levels in the newly diagnosed $\mathrm{mCRC}$ patients from the pre- and post-lockdown study cohorts.

Suppl. Figure 11: Scatter plots showing the correlation between LDH and cirDNA concentrations in pre and post-lockdown cohorts. Each dot represents the values of a single patient; slanting lines are the regression lines as performed by the Spearman test.

Suppl. Figure 12: Scatter plots showing the correlation between white blood cell count and cirDNA concentration in pre and post-lockdown cohorts. Each dot represents the values of a single patient; slanting lines are the regression lines as performed by the Spearman test.

Suppl. Figure 13: Scatter plots showing the correlation between CEA and cirDNA concentrations in pre and post-lockdown cohorts. Each dot represents the values of a single patient; slanting lines are the regression lines as performed by the Spearman test.

Suppl. Figure 14: Scatter plots showing the correlation between white blood cell count and LDH concentration in pre and post-lockdown cohorts. Each dot represents the values of a single patient; slanting lines are the regression lines as performed by the Spearman test. 
medRxiv preprint doi: https://doi.org/10.1101/2021.03.17.21253408; this version posted March 24, 2021. The copyright holder for this preprint (which was not certified by peer review) is the author/funder, who has granted medRxiv a license to display the preprint in All rights reserved. No reuse allowed without permission.

\section{Illustration of the correlation between cirDNA conc. and tumor burden}

Total cirDNA level ( $\mathrm{ng} / \mathrm{ml}$ of plasma)
21

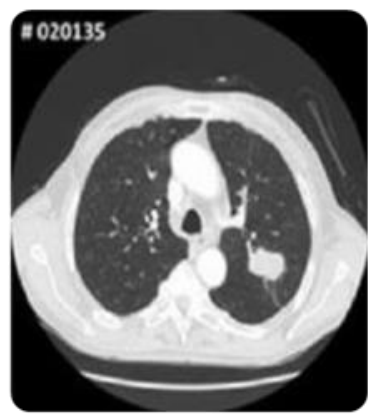

Tumor burden
$21.7 \mathrm{~cm}^{3}$

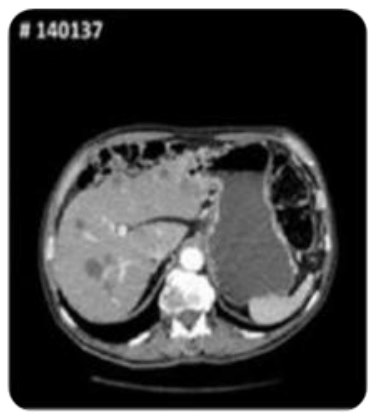

$68.6 \mathrm{~cm}^{3}$

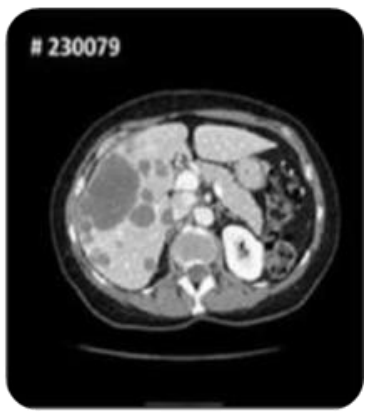

$422 \mathrm{~cm}^{3}$

Supplementary figure 1

Similar observation was reported by numerous other groups such as:

- Nygaard AD, Holdgaard PC, Spindler K-LG, Pallisgaard N, Jakobsen A. The correlation between cell-free DNA and tumour burden was estimated by PET/CT in patients with advanced NSCLC. Br J Cancer 2014;110:363-8

- Saluja, H.; Karapetis, C. S.; Pedersen, S. K.; Young, G. P.; Symonds, E. L. The Use of Circulating Tumor DNA for Prognosis of Gastrointestinal Cancers. Front. Oncol. 2018, 8, 275. https://doi.org/10.3389/fonc.2018.00275.

- Xu, X.; Yu, Y.; Shen, M.; Liu, M.; Wu, S.; Liang, L.; Huang, F.; Zhang, C.; Guo, W.; Liu, T. Role of Circulating Free DNA in Evaluating Clinical Tumor Burden and Predicting Survival in Chinese Metastatic Colorectal Cancer Patients. BMC Cancer 2020, 20 (1), 1006. https://doi.org/10.1186/s12885-020-07516-7.

- Hamfjord, J.; Guren, T. K.; Dajani, O.; Johansen, J. S.; Glimelius, B.; Sorbye, H.; Pfeiffer, P.; Lingjærde, O. C.; Tveit, K. M.; Kure, E. H.; Pallisgaard, N.; Spindler, K.-L. G. Total Circulating Cell-Free DNA as a Prognostic Biomarker in Metastatic Colorectal Cancer before First-Line Oxaliplatin-Based Chemotherapy. Annals of Oncology 2019, 30 (7), 1088-1095. https://doi.org/10.1093/annonc/mdz139. 
medRxiv preprint doi: https://doi.org/10.1101/2021.03.17.21253408; this version posted March 24, 2021. The copyright holder for this preprint (which was not certified by peer review) is the author/funder, who has granted medRxiv a license to display the preprint in

All rights reserved. No reuse allowed without permission.

AGE vs. cirDNA concentration

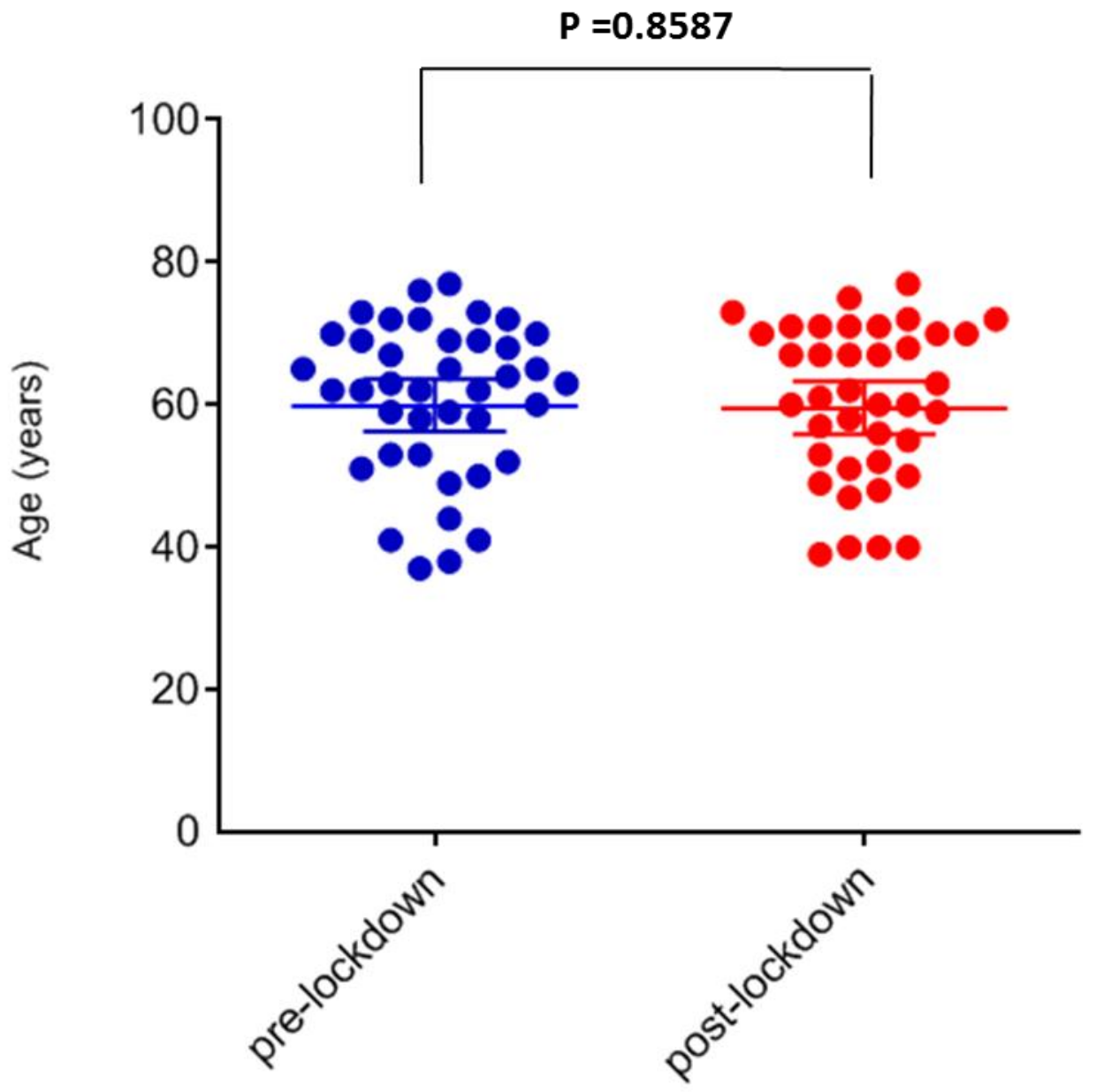

Supplementary figure 2 
medRxiv preprint doi: https://doi.org/10.1101/2021.03.17.21253408; this version posted March 24, 2021. The copyright holder for this preprint (which was not certified by peer review) is the author/funder, who has granted medRxiv a license to display the preprint in

All rights reserved. No reuse allowed without permission.

Gender of $m C R C$ patients

In the study cohort $(n=80)$

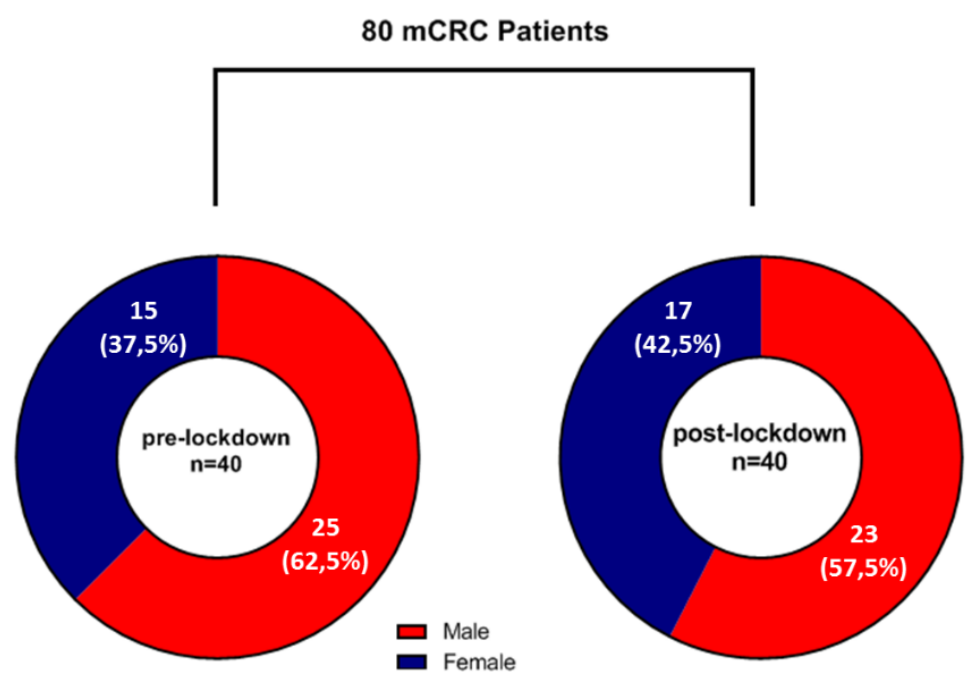

Supplementary figure 3 
medRxiv preprint doi: $h t t p s: / / d o i . o r g / 10.1101 / 2021.03 .17 .21253408$; this version posted March 24, 2021. The copyright holder for this preprint (which was not certified by peer review) is the author/funder, who has granted medRxiv a license to display the preprint in

perpetuity.
All rights reserved. No reuse allowed without permission.

\section{Delay of blood samples delivery $(n=80)$}

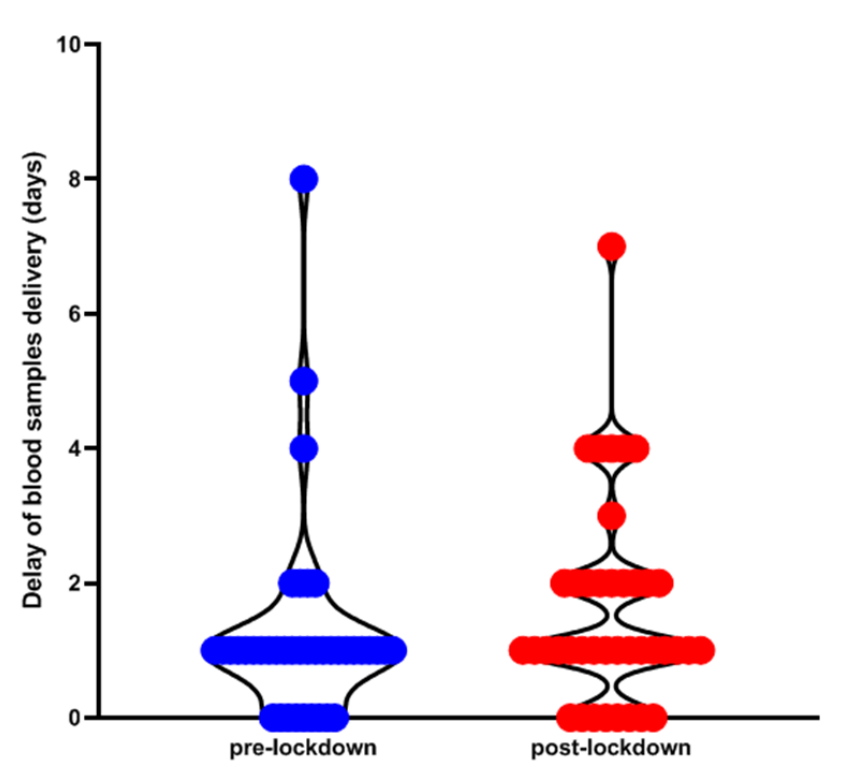

Table Analyzed

Column B

Column A

Mann Whitney test

$P$ value

Exact or approximate $P$ value?

$P$ value summary

Significantly different $(P<0.05)$ ?

One- or two-tailed $P$ value?

Sum of ranks in column $A, B$

Mann-Whitney U

Difference between medians

Median of column A

Median of column B

Difference: Actual

Difference: Hodges-Lehmann delay blood samples delivery

post-lockdown

pre-lockdown

$$
\begin{array}{r}
0,1198 \\
\text { Exact } \\
\mathrm{ns} \\
\mathrm{No} \\
\text { Two-tailed } \\
1470,1771 \\
649,5
\end{array}
$$

$1,000, n=40$

$1,000, n=40$

0,000

Supplementary figure 4 
medRxiv preprint doi: https://doi.org/10.1101/2021.03.17.21253408; this version posted March 24, 2021. The copyright holder for this preprint (which was not certified by peer review) is the author/funder, who has granted medRxiv a license to display the preprint in

perpetuity.
All rights reserved. No reuse allowed without permission.

\section{mutant circulating cell-free DNA concentration in mutant $\mathrm{mCRC}$ patients $(\mathrm{n}=48)$}

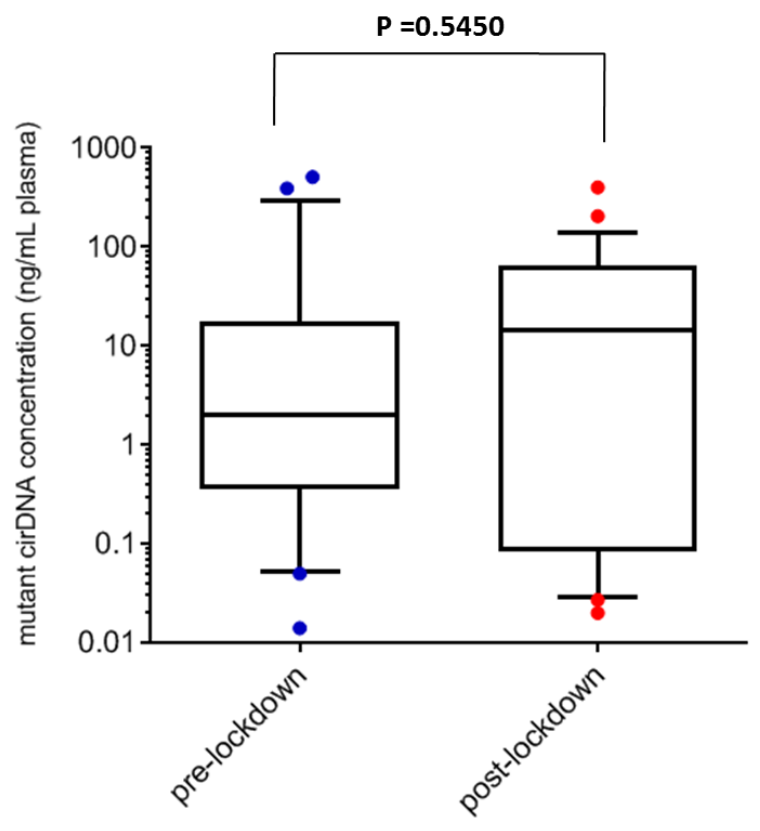

Table Analyzed

Column B

vs.

Column A

Mann Whitney test

$P$ value

Exact or approximate $P$ value?

$P$ value summary

Significantly different $(P<0.05)$ ?

One- or two-tailed $P$ value?

Sum of ranks in column A,B

Mann-Whitney U

Difference between medians

Median of column A

Median of column B

Difference: Actual

Difference: Hodges-Lehmann mutant cirDNA conc,

post-lockdown

vs,
pre-lockdown

$$
\begin{array}{r}
0,5450 \\
\text { Exact } \\
\mathrm{ns} \\
\text { No } \\
\text { Two-tailed } \\
509,667 \\
256
\end{array}
$$

$1,985, \mathrm{n}=22$

$14,21, \mathrm{n}=26$

12,23

1,710

Supplementary figure 5 
medRxiv preprint doi: https://doi.org/10.1101/2021.03.17.21253408; this version posted March 24, 2021. The copyright holder for this preprint (which was not certified by peer review) is the author/funder, who has granted medRxiv a license to display the preprint in

perpetuity.
All rights reserved. No reuse allowed without permission.

\author{
mutant alelle frequency \\ in mutant $\mathrm{mCRC}$ patients $(\mathrm{n}=48)$
}

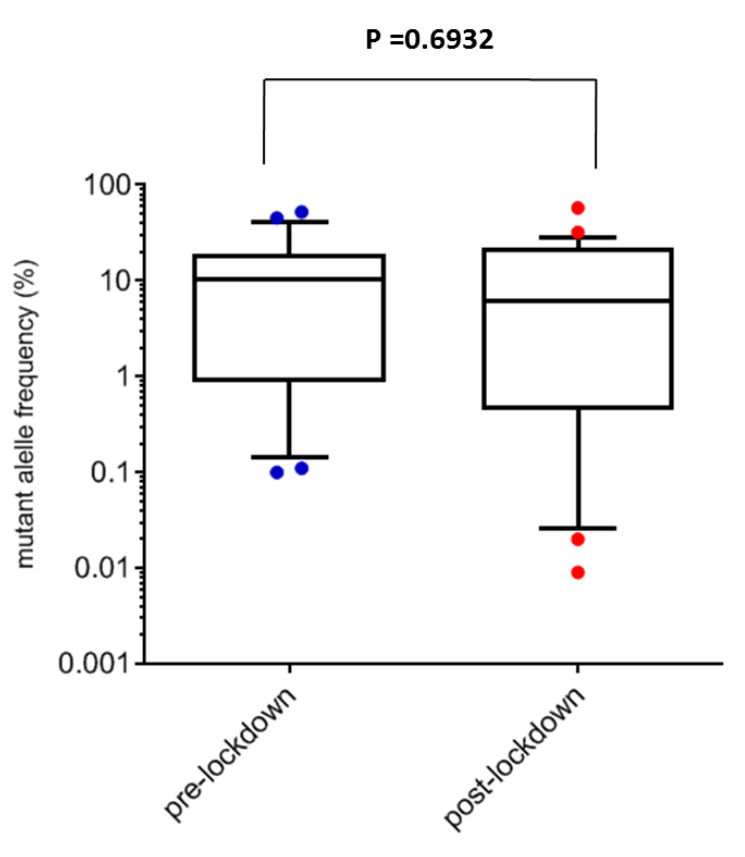

Table Analyzed

Column B

vs.

Column A

Mann Whitney test

$P$ value

Exact or approximate $P$ value?

$P$ value summary

Significantly different $(P<0.05)$ ?

One- or two-tailed $P$ value?

Sum of ranks in column $A, B$

Mann-Whitney $U$

Difference between medians

Median of column A

Median of column B

Difference: Actual

Difference: Hodges-Lehmann mutant allele frequency

post-lockdown

pre-lockdown,

0,6932

Exact

ns
No

Two-tailed $558,5,617,5$

266,5

$10,45, n=22$

$6,175, n=26$

$-4,270$

Supplementary figure 6 
medRxiv preprint doi: https://doi.org/10.1101/2021.03.17.21253408; this version posted March 24, 2021. The copyright holder for this preprint (which was not certified by peer review) is the author/funder, who has granted medRxiv a license to display the preprint in

perpetuity.
All rights reserved. No reuse allowed without permission.

$\operatorname{LDH}(n=56)$

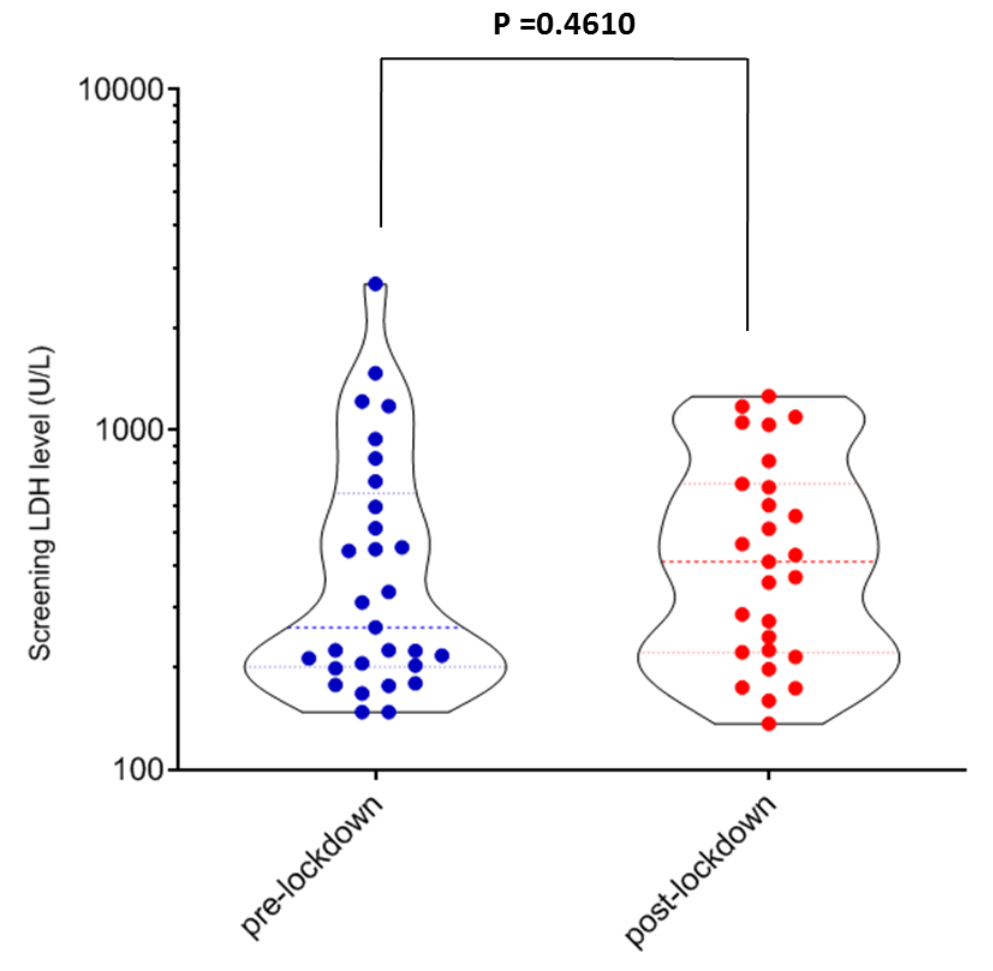

Table Analyzed

Column B

vs.

Column A

Mann Whitney test

$P$ value

Exact or approximate $P$ value?

$P$ value summary

Significantly different $(P<0.05)$ ?

One- or two-tailed $P$ value?

Sum of ranks in column $A, B$

Mann-Whitney U

Difference between medians

Median of column A

Median of column B

Difference: Actual

Difference: Hodges-Lehmann
LDH Lockdown

pre-lockdown

vs,

post-lockdown

$$
\begin{array}{r}
0,4610 \\
\text { Exact } \\
\mathrm{ns} \\
\text { No } \\
\text { Two-tailed } \\
781,815 \\
346
\end{array}
$$

$263,0, n=29$

$410,0, n=27$

147,0

42,00

Supplementary figure 7 
medRxiv preprint doi: https://doi.org/10.1101/2021.03.17.21253408; this version posted March 24, 2021. The copyright holder for this preprint (which was not certified by peer review) is the author/funder, who has granted medRxiv a license to display the preprint in

perpetuity.
All rights reserved. No reuse allowed without permission.

White blood cell count $(n=61)$

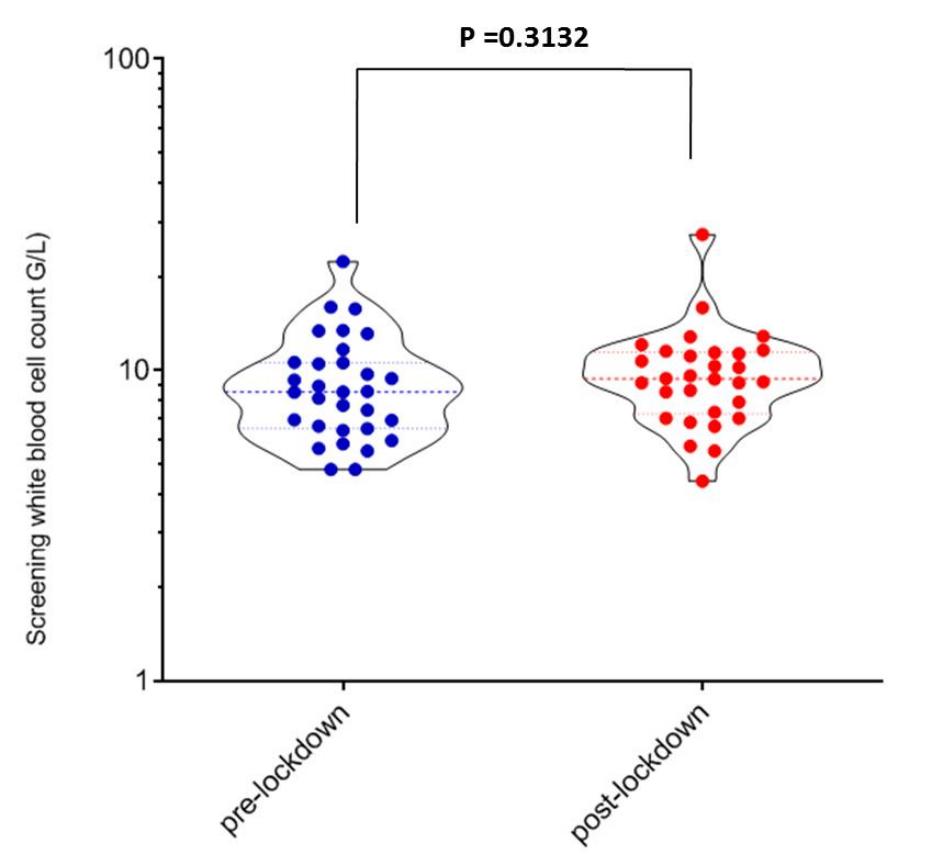

Table Analyzed

Column B

vs.

Column A

Mann Whitney test

$P$ value

Exact or approximate $P$ value?

$P$ value summary

Significantly different $(P<0.05)$ ?

One- or two-tailed $P$ value?

Sum of ranks in column $A, B$

Mann-Whitney U

Difference between medians

Median of column A

Median of column B

Difference: Actual

Difference: Hodges-Lehmann
White blood cell count

pre-lockdown

post-ockdown

0,3132

Exact

ns

Two-tailed $890,5,1001$

394,5

$8,510, n=31$

$9,385, n=30$

0,8750

Supplementary figure 8 
medRxiv preprint doi: https://doi.org/10.1101/2021.03.17.21253408; this version posted March 24, 2021. The copyright holder for this preprint (which was not certified by peer review) is the author/funder, who has granted medRxiv a license to display the preprint in

perpetuity.
All rights reserved. No reuse allowed without permission.

\section{$\operatorname{CEA}(n=61)$}

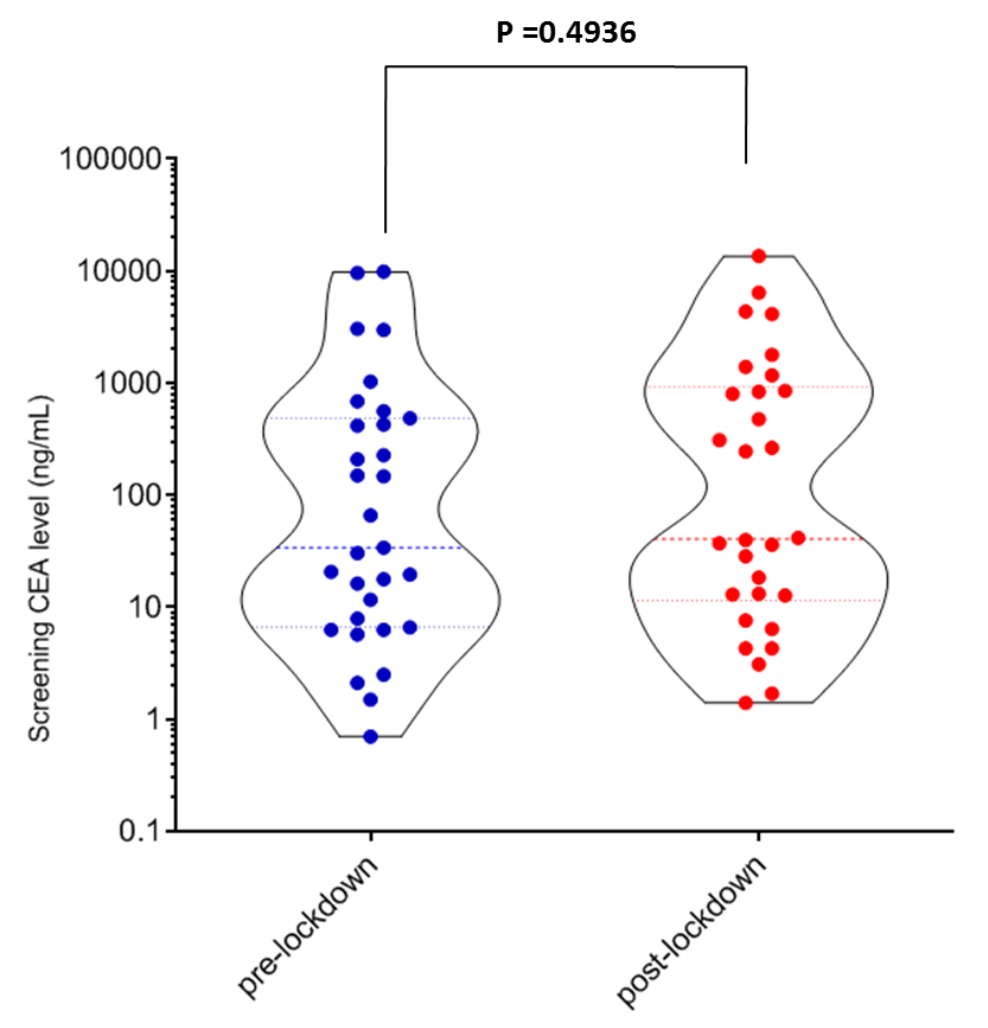

Table Analyzed

Column B

vs.

Column A

Mann Whitney test

$P$ value

Exact or approximate $P$ value?

$P$ value summary

Significantly different $(P<0.05)$ ?

One- or two-tailed $P$ value?

Sum of ranks in column A,B

Mann-Whitney U

Difference between medians

Median of column A

Median of column B

Difference: Actual

Difference: Hodges-Lehmann
CEA Lockdown

pre-lockdown

vs,

post-lockdown

$$
\begin{array}{r}
0,4936 \\
\text { Exact } \\
\mathrm{ns} \\
\text { No } \\
\text { Two-tailed } \\
913,978 \\
417
\end{array}
$$

$34,00, n=31$

$40,75, n=30$

6,750

6,700

Supplementary figure 9 
medRxiv preprint doi: https://doi.org/10.1101/2021.03.17.21253408; this version posted March 24, 2021. The copyright holder for this preprint (which was not certified by peer review) is the author/funder, who has granted medRxiv a license to display the preprint in

All rights reserved. No reuse allowed without permission.

LDH, CEA and white blood cell count vs. cirDNA
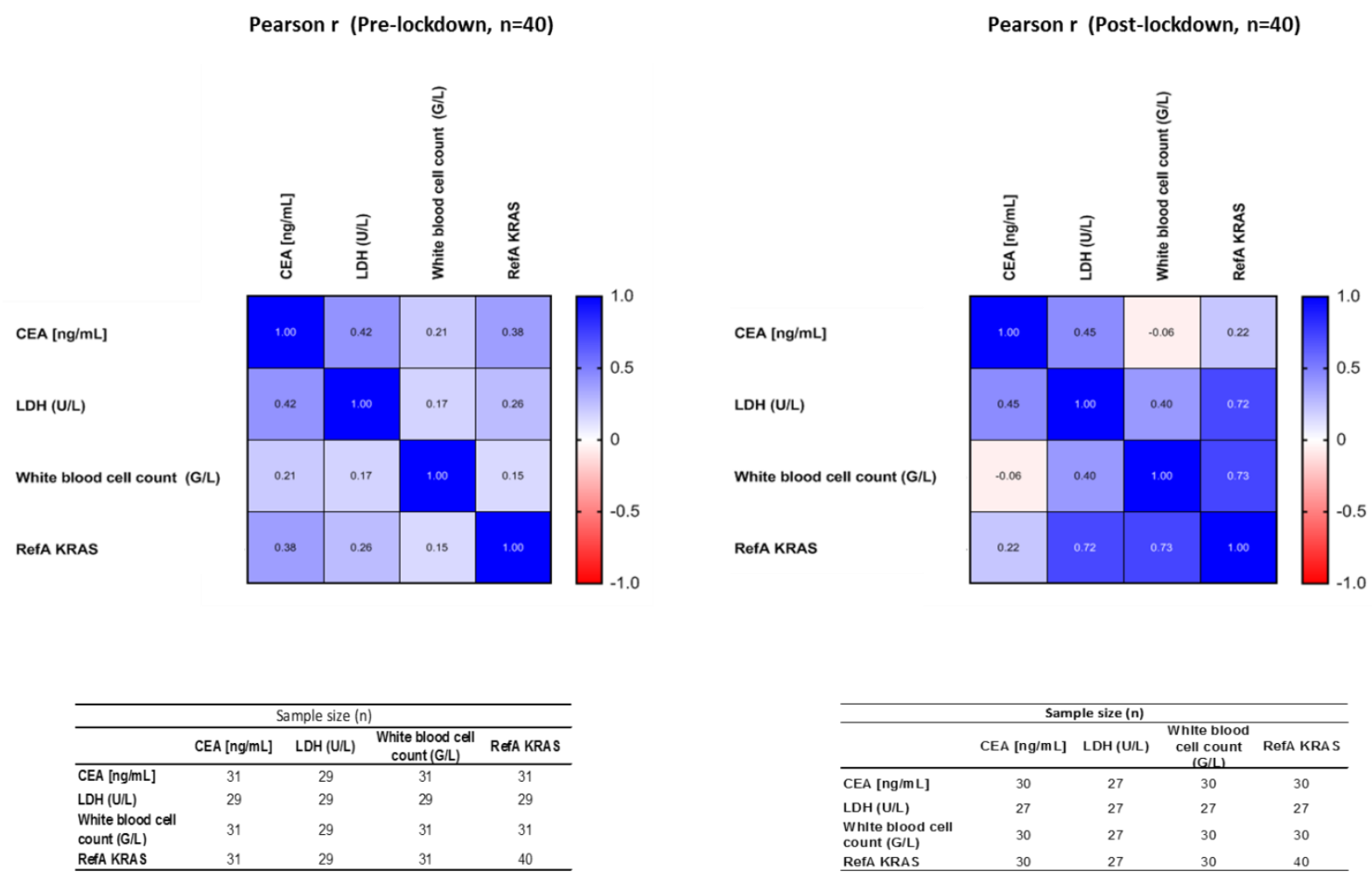

Supplementary figure 10

\begin{tabular}{lcccc}
\hline \multicolumn{5}{c}{ Sample size (n) } \\
\hline & CEA [ng/mL] & LDH (U/L) & $\begin{array}{c}\text { White blood } \\
\text { cell count } \\
\text { (G/l) }\end{array}$ & RefA KRAS \\
\hline CEA [ng/mL] & 30 & 27 & 30 & 30 \\
LDH (U/L) & 27 & 27 & 27 & 27 \\
White blood cell & 30 & 27 & 30 & 30 \\
count (GL) & 30 & 27 & 30 & 40 \\
RefA KRAS & \multicolumn{4}{c}{}
\end{tabular}


medRxiv preprint doi: $h t t p s: / / d o i . o r g / 10.1101 / 2021.03 .17 .21253408$; this version posted March 24, 2021. The copyright holder for this preprint (which was not certified by peer review) is the author/funder, who has granted medRxiv a license to display the preprint in

perpetuity.
All rights reserved. No reuse allowed without permission.

LDH levels (U/L) vs. cirDNA (ng/mL plasma)

Pre-lockdown

(LDH, $n=29)$

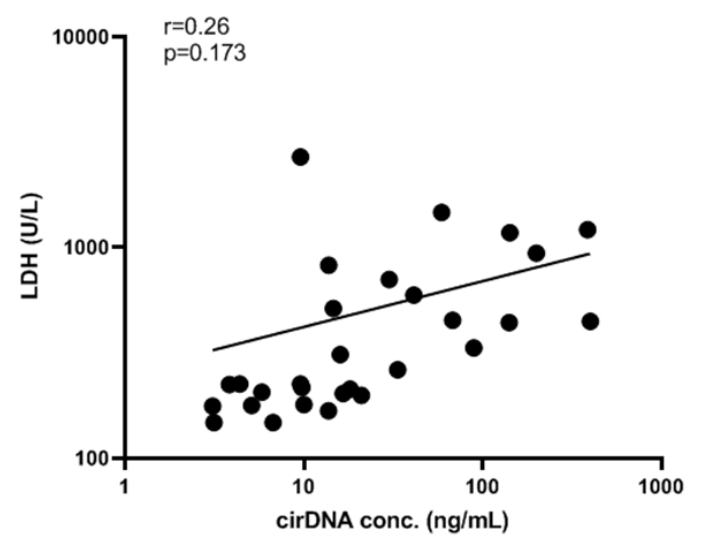

Post-lockdown

(LDH, n=27)

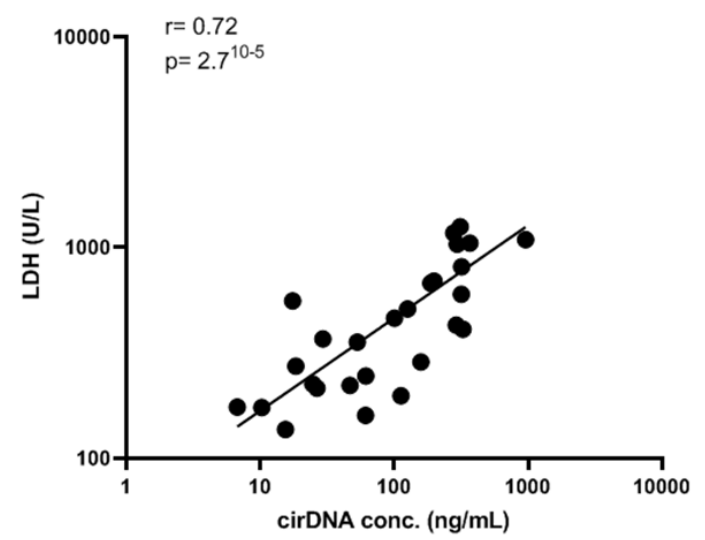

Supplementary figure 11 
medRxiv preprint doi: $h t t p s: / / d o i . o r g / 10.1101 / 2021.03 .17 .21253408$; this version posted March 24, 2021. The copyright holder for this preprint (which was not certified by peer review) is the author/funder, who has granted medRxiv a license to display the preprint in

perpetuity.
All rights reserved. No reuse allowed without permission.

White blood cell count (G/L) vs. cirDNA ( $\mathrm{ng} / \mathrm{mL}$ plasma)

Pre-lockdown

(White blood cell count, $n=31$ )
Post-lockdown

(White blood cell count, $n=30$ )
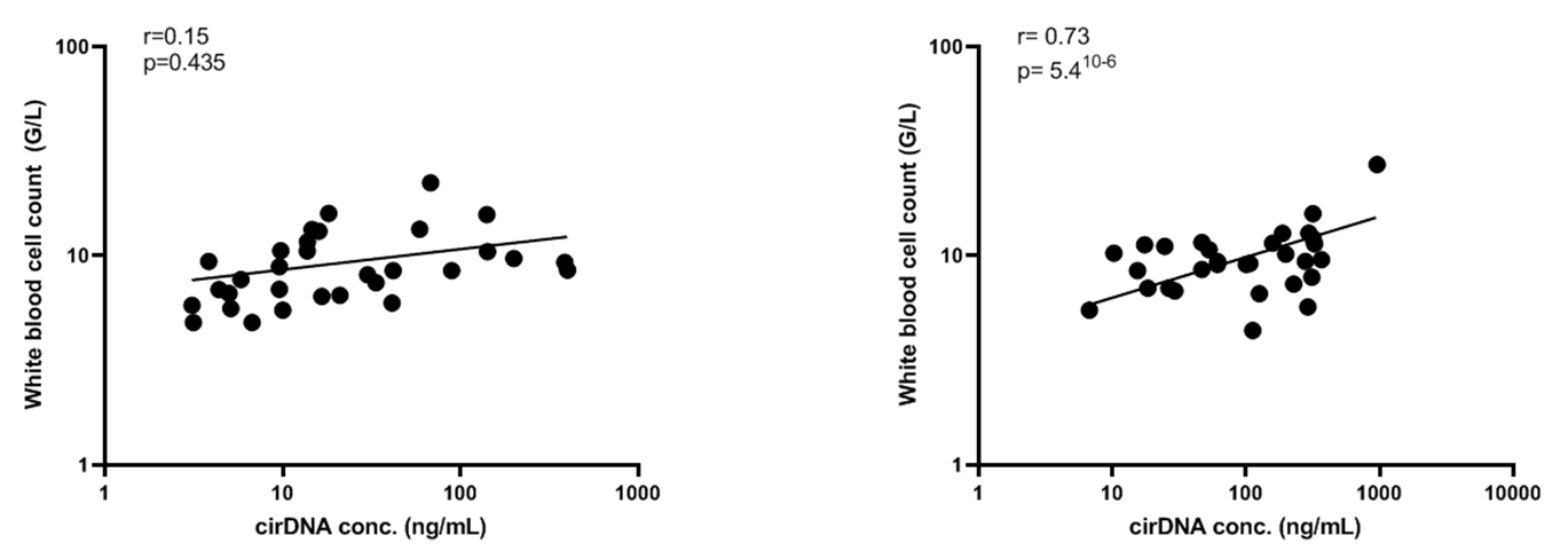

Supplementary figure 12 
medRxiv preprint doi: $h t t p s: / / d o i . o r g / 10.1101 / 2021.03 .17 .21253408$; this version posted March 24, 2021. The copyright holder for this preprint (which was not certified by peer review) is the author/funder, who has granted medRxiv a license to display the preprint in

perpetuity.
All rights reserved. No reuse allowed without permission.

CEA levels ( $\mathrm{ng} / \mathrm{mL}$ palsma) vs. cirDNA (ng/mL plasma)

Pre-lockdown

(CEA, $n=31)$

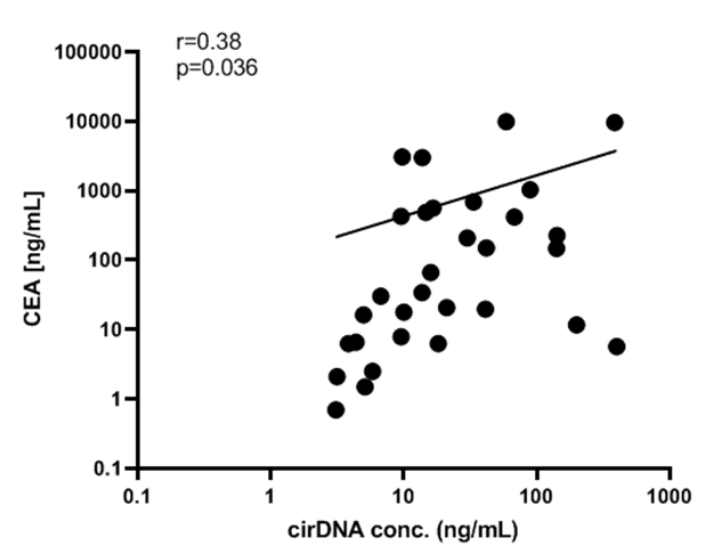

Post-lockdown

(CEA, $n=30)$

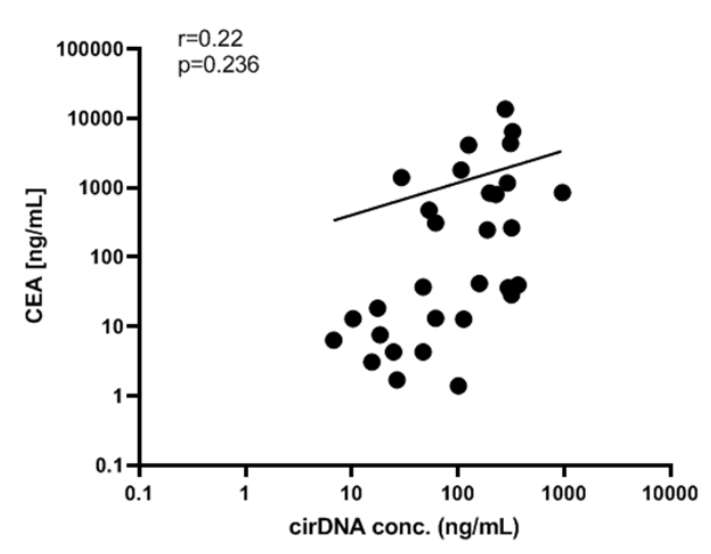

Supplementary figure 13 
medRxiv preprint doi: $h t t p s: / / d o i . o r g / 10.1101 / 2021.03 .17 .21253408$; this version posted March 24, 2021. The copyright holder for this preprint (which was not certified by peer review) is the author/funder, who has granted medRxiv a license to display the preprint in

perpetuity.
All rights reserved. No reuse allowed without permission.

White blood cell count (G/L) vs. LDH (U/L)

Pre-lockdown ( $n=29$ )

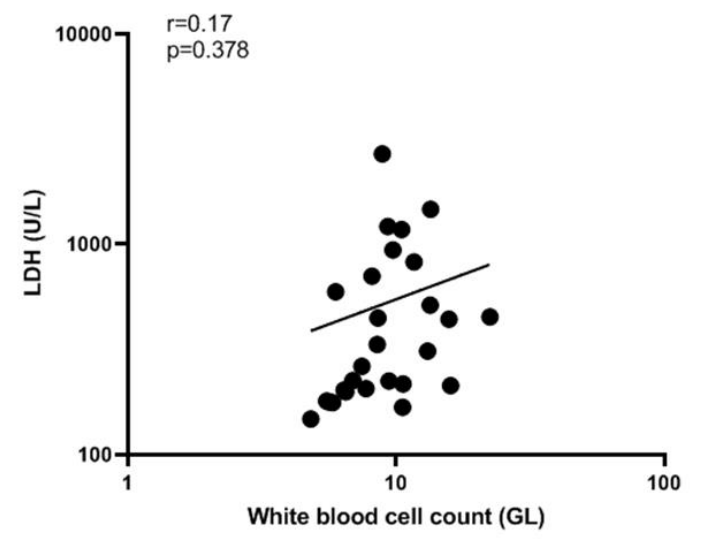

Post-lockdown

$(n=27)$

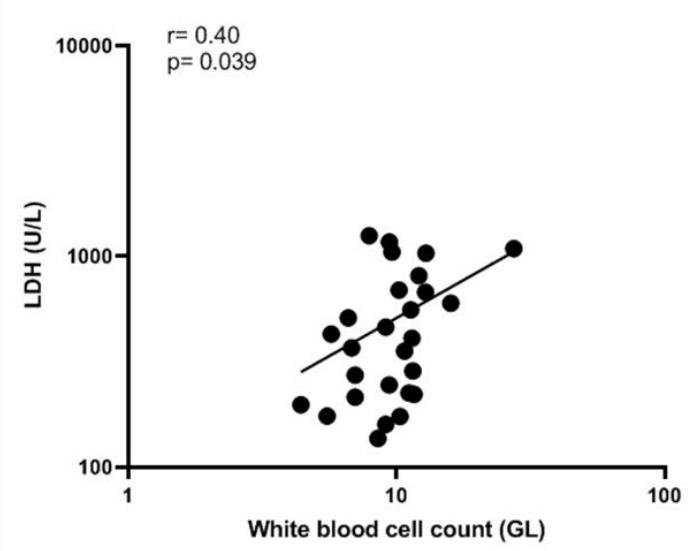

Supplementary figure 14 
medRxiv preprint doi: https://doi.org/10.1101/2021.03.17.21253408; this version posted March 24, 2021. The copyright holder for this preprint (which was not certified by peer review) is the author/funder, who has granted medRxiv a license to display the preprint in

perpetuity.
All rights reserved. No reuse allowed without permission.

\section{Supplementary Table 1}

\begin{tabular}{|c|c|c|c|c|}
\hline \multicolumn{5}{|l|}{ CirDNA analysis } \\
\hline & \multicolumn{3}{|c|}{ Cohorts N (\%) } & \multirow[b]{2}{*}{$\begin{array}{l}\text { Mann Whitney test } \\
\text { pre- vs. post-lockdowr } \\
\text { (pvalue) }\end{array}$} \\
\hline & Full study cohort & Pre-lockdown & Post-lockdown & \\
\hline $\mathbf{N}$ & $80(100 \%)$ & $40(50 \%)$ & $40(50 \%)$ & \\
\hline \multicolumn{5}{|l|}{ CirDNA conc. (ng/mL plasma) } \\
\hline Median (IQR) & $43,35(15,47-195,4)$ & $17,27(9,57-399,7)$ & $119,2(43,38-315,8)$ & $p<0.0001$ \\
\hline Min-Max & $3,9-1852$ & $3,09-396,6$ & 6,74-1852 & \\
\hline \multicolumn{5}{|l|}{ Mutational status } \\
\hline Wild type & $32(40 \%)$ & $18(45 \%)$ & $14(35 \%)$ & \\
\hline Mutant & $48(60 \%)$ & $22(55 \%)$ & $26(65 \%)$ & \\
\hline \multicolumn{5}{|c|}{ Point mutation found in mutant patients } \\
\hline KRAS & 41 & 23 & 18 & \\
\hline G12A & 4 & 2 & 2 & \\
\hline G12V & 15 & 8 & 7 & \\
\hline G12S & 4 & 1 & 3 & \\
\hline$G 12 D$ & 5 & 2 & 3 & \\
\hline$G 12 R$ & 1 & 0 & 1 & \\
\hline$G 13 D$ & 6 & 5 & 1 & \\
\hline A146T & 3 & 2 & 1 & \\
\hline Al46V & 1 & 1 & 0 & \\
\hline Q61H-AC & 2 & 2 & 0 & \\
\hline \multicolumn{5}{|l|}{ BRAF } \\
\hline V600E & 5 & 3 & 2 & \\
\hline NRAS & 4 & 1 & 3 & \\
\hline G12C & 1 & 0 & 1 & \\
\hline$G 12 D$ & 1 & 1 & 0 & \\
\hline$Q 61 R$ & 1 & 0 & 1 & \\
\hline$Q 61 H-A C$ & 1 & 0 & 1 & \\
\hline \multicolumn{5}{|c|}{ Mutant cirDNA concentration (ng/mL plasma) } \\
\hline Median (IQR) & $5,26(0,17-37,65)$ & $1,99(0,35-17,96)$ & $14,21(0,08-65,03)$ & $p=0.5450$ \\
\hline Min-Max & $0,014-510,5$ & $0,014-510,5$ & $0,02-401,9$ & \\
\hline \multicolumn{5}{|l|}{ Mutant allele frequency (\%) } \\
\hline Median (IQR) & $7,20(0,64-21,63)$ & $10,45(0,88-19,22)$ & $6,18(0,45-21,96)$ & $p=0.6932$ \\
\hline Min-Max & $0,009-57-93$ & $0,1-52,20$ & $0,009-57,93$ & \\
\hline
\end{tabular}


medRxiv preprint doi: https://doi.org/10.1101/2021.03.17.21253408; this version posted March 24, 2021. The copyright holder for this preprint (which was not certified by peer review) is the author/funder, who has granted medRxiv a license to display the preprint in

perpetuity.
All rights reserved. No reuse allowed without permission.

\section{Supplementary Table 2}

\begin{tabular}{|c|c|c|c|c|c|c|c|c|}
\hline \multicolumn{9}{|c|}{ Cox models data on median survival } \\
\hline & $\begin{array}{l}\text { Dichotomisation: } \\
\text { cirDNA conc. cut-off } \\
\text { (ng/mL plasma) }\end{array}$ & effectif $(n)$ & $\begin{array}{l}\text { median survival } \\
\text { (months) }\end{array}$ & $\begin{array}{l}\text { median survival } \\
\text { equal or below cut- } \\
\text { off (months) }\end{array}$ & $\begin{array}{c}\text { median survival } \\
\text { over cut-off } \\
\text { (months) }\end{array}$ & Hazard Ratio (HR) & $\begin{array}{c}\mathrm{Cl} 95 \% \text { of median } \\
\text { survivals }\end{array}$ & Cox models ( $p$ value) \\
\hline Figure $2 \mathrm{~A}$ & NA & 135 & 48,7 & & & & {$[13,6-20,6]$} & \\
\hline Figure $2 \mathrm{~B}$ & 24,4 & 135 & 48,7 & 20 & 14,7 & 1,74 & {$[1,2-2,6]$} & 0,005 \\
\hline Figure $2 \mathrm{C}$ & 100 & 135 & 48,7 & 19,3 & 8,8 & 2 & {$[1,2-3,3]$} & 0,009 \\
\hline \multicolumn{9}{|c|}{ legend: } \\
\hline C195\%: 95\% & nfidence Interval & & & & & & & \\
\hline
\end{tabular}

